\title{
マイクロチャンネル熱交換器流路系の気体流れの圧力損失予測に関する研究
}

\author{
村上 信太郎 ${ }^{* 1}$ ，豊田 香*1，浅古 豊 ${ }^{* 2}$
}

\section{Pressure loss prediction of gaseous flow in a conduit-system of microchannel heat exchanger}

\author{
Shintaro MURAKAMI ${ }^{* 1}$, Kaoru TOYODA*1 and Yutaka ASAKO ${ }^{* 2}$ \\ ${ }^{* 1}$ National Institute of Technology, Maizuru College \\ 234 Shiroya, Maizuru-shi, Kyoto 625-8511, Japan \\ ${ }^{* 2}$ Malaysia-Japan International Institute of Technology, University Technology Malaysia \\ Jalan Sultan Yahya Petra, Kuala Lumpur 54100, Malaysia
}

Received: 20 January 2020; Revised: 11 March 2020; Accepted: 24 March 2020

\begin{abstract}
Three methods for predicting pressure loss of gaseous flow in a conduit-system of microchannel heat exchanger are proposed and discussed. In the experiment, the heat transfer plate which is the core of the heat exchanger has 34 rectangular microchannels. The microchannels are $330 \mu \mathrm{m}$ in width, $200 \mu \mathrm{m}$ in depth and $20 \mathrm{~mm}$ in length. The working fluid is air at room temperature, which is compressed to flow in the heat exchanger and flows out to atmospheric surroundings. The static pressures were measured at the inlet and outlet of the conduit-system. The conduit-system, namely, the heat exchanger and the piping system, includes several factors of pressure loss such as pipe friction, sudden expansion or contraction at the joints of piping system, besides the conventional loss at the heat exchanger core. These additional losses cannot be ignored because the hydraulic diameters of piping system tend to be small for microchannel heat exchangers. The prediction methods are formulated with the assumption that the pressure loss coefficients (such as pipe friction factor) have the same value of those of incompressible flow. One of the methods is simply formulated assuming isothermal flow and constant densities in each conduit-element, and another one is based on one-dimensional adiabatic flow theory. These two methods adopted pressure loss correlation of incompressible flow as approximation. The third method adopted modified pressure loss correlation where the essence of pressure loss is considered as internal heat generation by dissipation, and total pressure loss is calculated based on isobaric curves on h-s chart using entropy increase by the heat generation. When the measured outlet pressure is used as initial value of prediction, the third method gives the best prediction of static pressure difference between the inlet and outlet of the conduit-system within 3.9\% difference from the experiment in the range of 371-1460 of channel Reynolds number.
\end{abstract}

Keywords : Microchannel, Heat exchanger, Gaseous flow, Pressure loss, Prediction mtehod, One-dimensional flow

\section{1. 緒言}

機械的微細加工や MEMS 加工技術などで造形されるマイクロ流路によって熱交換器を小型化・高性能化する研 究が進められている．例えば，空調機用コルゲートフィン型熱交換器の冷媒流路にマイクロ流路を用いることで 従来のクロスフィンチューブ型熱交換器と同等の性能が約半分の大きさで実現されており (Hayase, 2016), カセッ トエアコンの製品 (サムスン電子社, AC120MNMDKH/EU) に搭載され始めている. 電子機器の分野では, 3D IC・ 2.nD IC のようなシリコンダイ集積化技術の発展に伴ってパッケージの発熱密度が増加し, 対策が急務になってい る. 発熱する素子の泠却方法として基板にマイクロ流路を内蔵して冷媒を流寸方法が有効であることが古くから 提唱されていた(Tuckerman and Pease, 1981)が, 近年 Sarvey らによって市販の FPGA のシリコンダイ上に直接造形 した直径 $100 \mu \mathrm{m}$ の多数のピン型フィンに水を流して冷却する実験が行われ，標準的なファンによる空冷ヒート シンクと比べてきわめて効率の良い除熱ができることが実証されている(Sarvey et al., 2015).

No.20-00022 [DOI:10.1299/transjsme.20-00022], J-STAGE Advance Publication date : 2 April, 2020

*1 正員, 舞鶴工業高等専門学校（广625-8511 京都府舞鶴市白屋 234）

*2 マレーシア日本国際工科院，マレーシア工科大学（Jalan Sultan Yahya Petra, Kuala Lumpur 54100, Malaysia)

E-mail of corresponding author: s.murakami@maizuru-ct.ac.jp 
熱交換器の設計では流体輸送装置や運転コスト検討のための圧力損失予測が必要となる．多数の流路あるいは フィンなどによって伝熱面を拡大した熱交換器コアは流路が狭小・複雑となるので, 従来の設計手法では熱交換 器の主要な圧力損失はコアで生じるとされている(坪内，1968). よって，マイクロ流路をコアに用いた熱交換器 の圧力損失を予測するには，まず単一のマイクロ流路（マイクロチャンネル／チューブ）に生じる損失を知る必 要がある. マイクロ流路の管摩擦係数は, 報告ごとに通常の関係式（層流の $64 / R e$, または乱流のブラジウス の式）の值から上下にばらつき，定まった見解が得られない状況が長く続いてきた(Papautsky et al., 1999). しかし 近年 Yen ら(Yen et al., 2003), あるいは Kohl ら(Kohl et al., 2005)の精密な実験によって, 直径数十〜数百 $\mu \mathrm{m}$ のマイ クロチューブの非圧縮性流れの管摩擦係数は通常の関係式と同じ值になることが確認された. これらの研究成果 により, 過去の多数の報告で見られた通常の関係式との差異について, 摩擦以外の損失（入口および出口損失, 圧力測定孔の損失）が加算されていたこと，流路寸法の誤差，気体を用いた実験では圧縮性が現れる条件下のデ 一タに対しその影響を適切に考慮した整理がなされていなかったことなどが原因という見解が固まりつつある (マイクロ・ナノ熱流体ハンドブック編集委員会, 2006). 圧縮性流れについては, 管壁が滑らかかつ希薄気体効 果が無視できる範囲で, 直径 $10 \mu \mathrm{m} \sim 200 \mu \mathrm{m}$ のマイクロチューブに対する層流の数值計算結果の局所ファニング 摩擦係数がレイノルズ数とマッ八数によって整理され, その整理式を用いて 1 次元流れの方程式を解くことで圧 力損失を予測できることが示されている(村上，浅古，2011). 乱流の場合も，147 $\mu \mathrm{m}$ および $203 \mu \mathrm{m}$ の等価直径 を有する矩形断面マイクロチャンネルを用いた実験(Hong et al., 2016)によって, 管摩擦係数がブラジウスの式と ほぼ一致することが示されている.

このように, 単一のマイクロ流路に対しては摩擦損失の特性がある程度明らかにされ, 圧力損失予測に必要な 知見が整備されつつある. 一方, 熱交換器全体で見た場合は, 伝熱面・熱交換器本体に流体を出入りさせるため の流路を含めると，曲がり・急拡大/縮小・分岐合流などの複数の要素で構成された流路系となるのが一般的で ある. 熱交換器コアにマイクロ流路を用いる場合, コア周囲の流路系も狭小となることが考えられる. 電子機器 の冷却では機器保全の観点から冷却用流体として気体を用いることも有力となるが，気体の流れでは損失による 圧力低下に伴って膨張加速が起こるため, コア周囲の狭小流路で速度が大きくなり，そこで生じる損失が熱交換 器全体の圧力損失に与える影響が無視できなくなる．したがってマイクロ流路をコアに用いる熱交換器の設計に は，コアだけでなく周囲の流路系を含めた包括的な圧力損失予測が必要になるが，圧縮性流れに対しては方法が 十分に確立されておらず, 例えば熱交換器本体に流体を出入りさせる接続管の上流・下流の静圧差の予測計算值 が実験值の 10 分の 1 程度の大きさにしかならなかったという報告もある(Koyama and Asako, 2010).

そこで本研究では, 動作流体が空気の場合について, 多数の矩形断面マイクロチャンネルを有する伝熱プレー ト，およびその伝熱プレートに空気を出入りさせる配管系を含めた熱交換器流路系全体の圧力損失を予測するた めの方法を提案し, 実験との比較によって妥当性を検討した.

\section{記号}

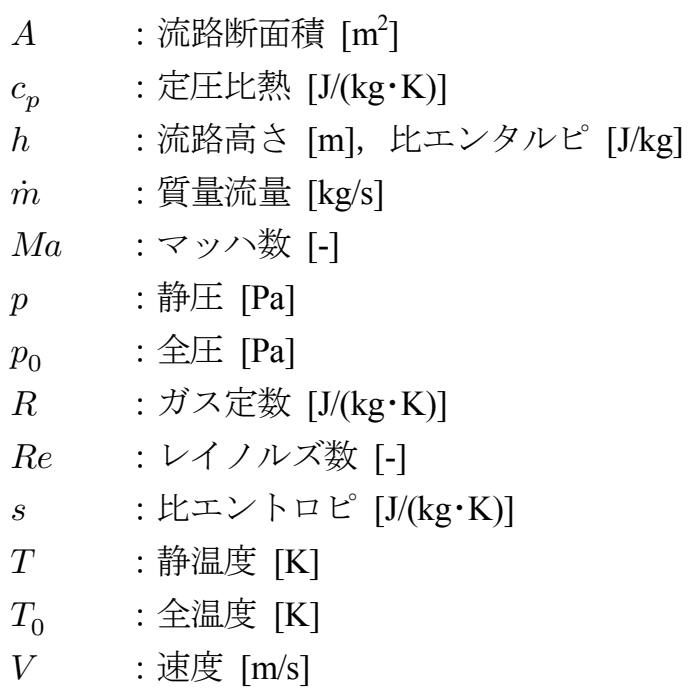




$$
\begin{array}{ll}
\kappa & : \text { 比熱比 }[-] \\
\mu & : \text { 粘度 }[\mathrm{Pa} \cdot \mathrm{s}] \\
\rho & : \text { 密度 }\left[\mathrm{kg} / \mathrm{m}^{3}\right]
\end{array}
$$

\section{2. 圧力損失の予測}

\section{$2 \cdot 1$ 熱交換器の構造・寸法}

本研究では Institut für Mikrotechnik Mainz 社製マイクロチャンネル熱交換器 COMH に常温空気を流す場合の圧 力損失予測を行う. COMH の外観を図 1 に示す. COMH はプレート式熱交換器で，複数枚の (i) 伝熱プレート

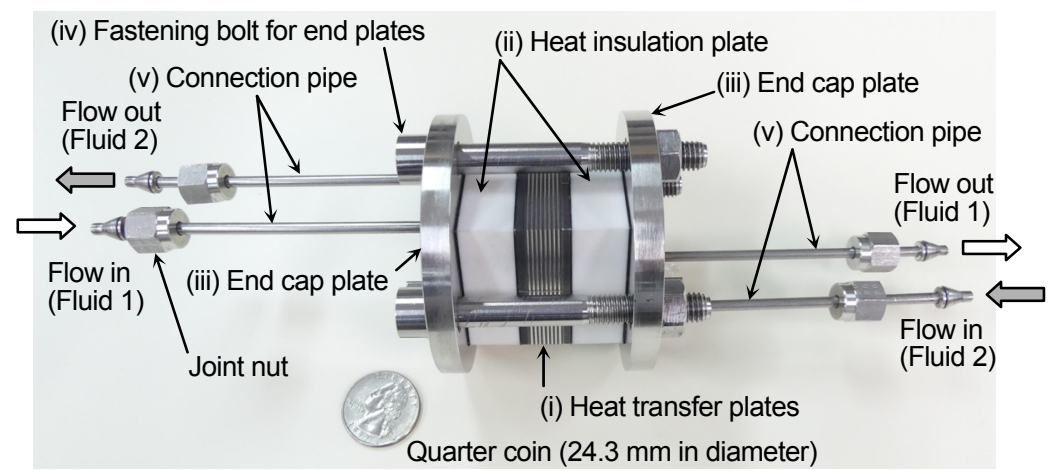

Fig. 1 The microchannel heat exchanger, COMH. The (i) heat transfer plates and (ii) insulation plates are stacked between (iii) end cap plates and fixed by (iv) fastening bolts. (v) Connection pipes are welded on the end cap plates. The fluids are led to the heat exchanger and exhausted through these connection pipes.

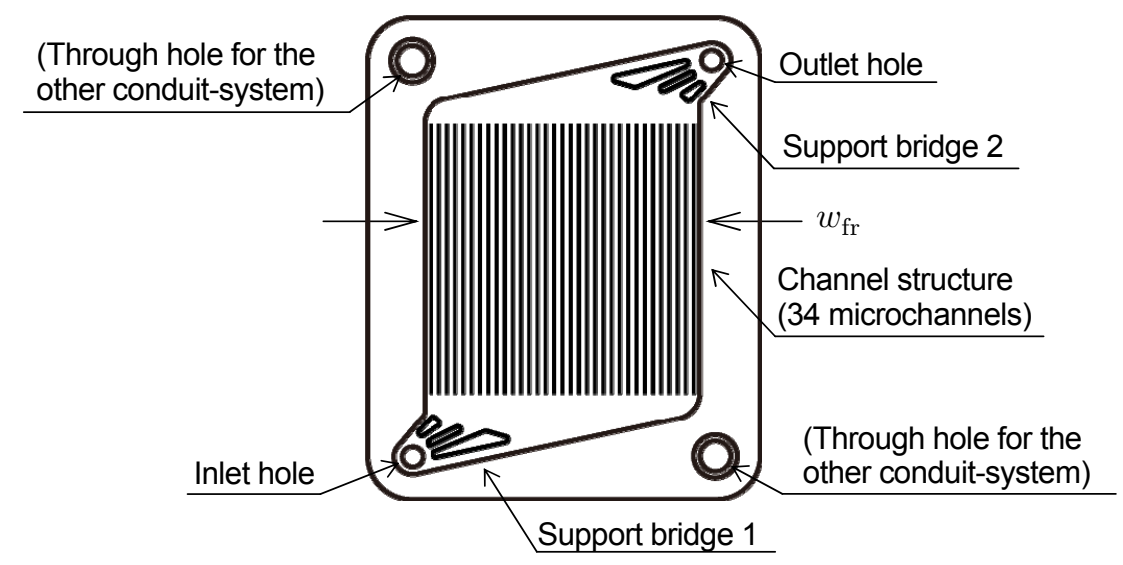

Fig. 2 The conduit on the heat transfer plate. The conduit geometry is center-point symmetric. The conduit has 34 microchannels which is the core of the heat exchanger. Beside inlet/outlet hole, there are support bridges guiding fluid flow between the hole and the core.

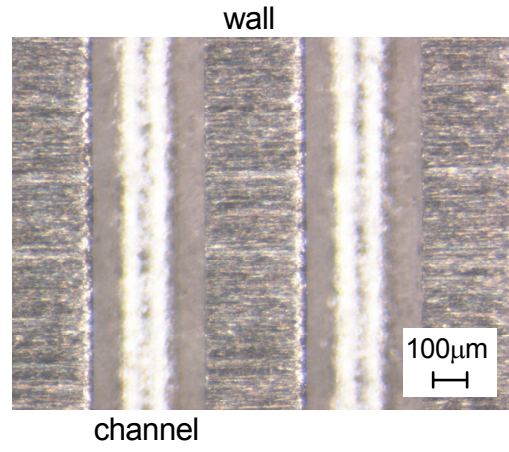

(a) Microchannels (50x).

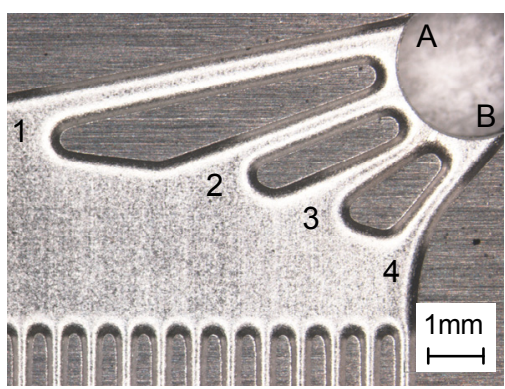

(b) Support bridge (10x).

Fig. 3 Micrograph of the heat transfer plate surface. The measured channel width is $330 \mu \mathrm{m}$, and partition wall thickness is $260 \mu \mathrm{m}$. 


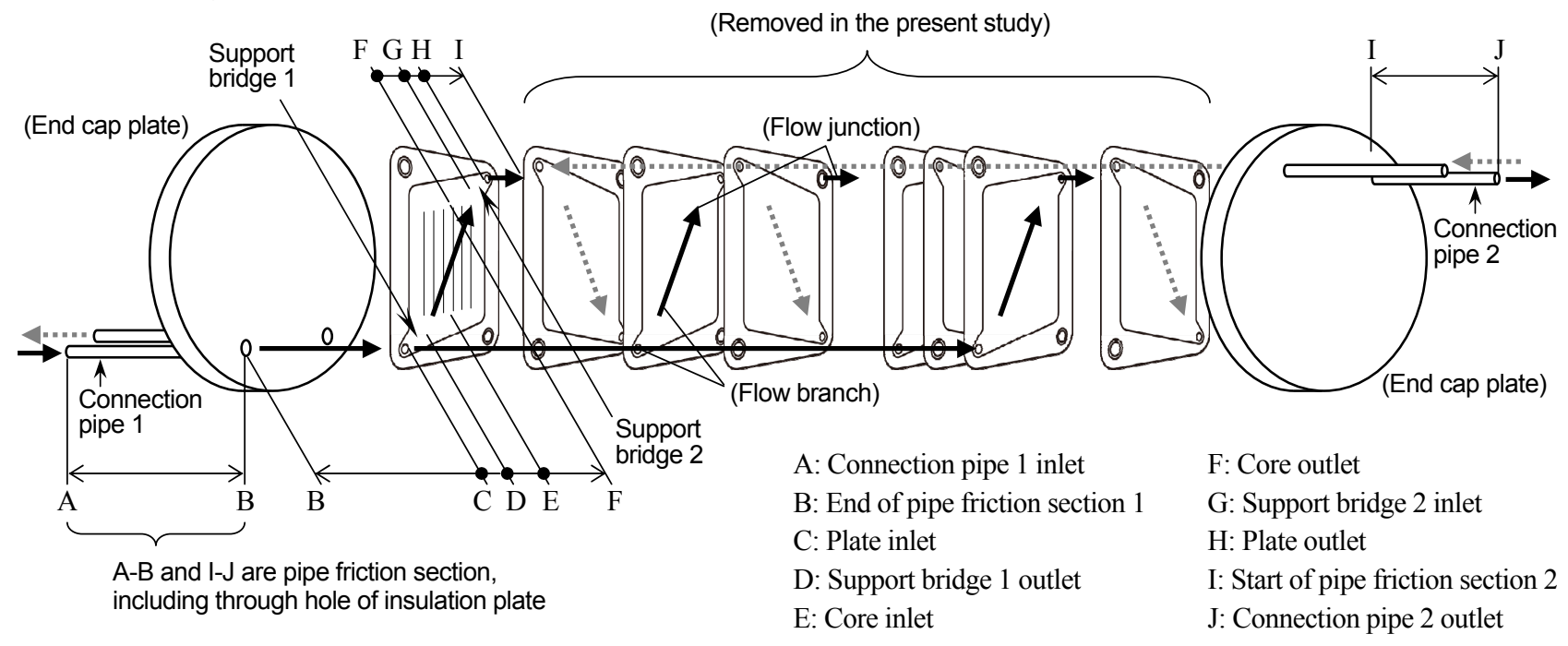

(a) Illustration of the flow path in COMH. Two conduit-systems (1 and 2) are constructed.

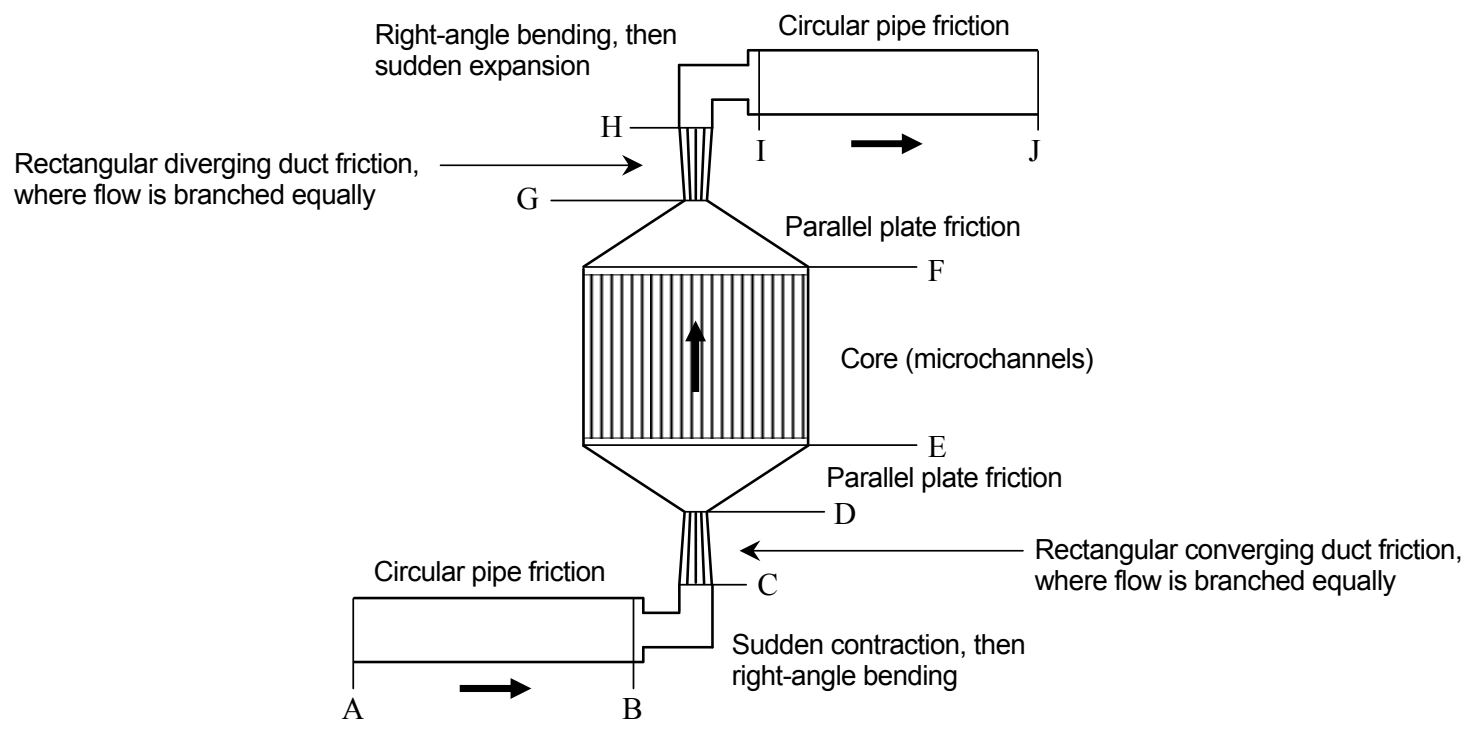

(b) Schematic diagram of modeling of the conduit-system by the 9 conduit-elements, A-B, B-C, ..., and I-J.

Fig. 4 Flow path in COMH and the prediction model. In (a), two conduit-systems constructed in COMH are illustrated. These two conduit-systems have the same geometry and dimension, except flow direction. This conduit-system is modeled by 9 conduit-elements as shown in (b).

（SUS316Ti）を (ii) 断熱板（MACOR ${ }^{\circledR}$-glass-ceramics）ではさみ，(iii) エンドキャップ円板（SUS316Ti）を介し て (iv) ボルトで締結した構造となっている. それぞれのエンドキャップ円板には 2 本の (v) 接続管 (SUS316Ti) が溶接されている. 以上を熱交換器本体とし, その上流・下流の静圧の差を予測する.

伝熱プレートの厚さは $0.5 \mathrm{~mm}$ で, 深さ $200 \mu \mathrm{m}$ の湿式エッチング加工によって図 2 に示寸形状の流路が造形さ れている. 流路は中心点に関して対称な形状である. 流路中央部が熱交換器コアとなっており, 幅 $330 \mu \mathrm{m}$, 深さ $200 \mu \mathrm{m}$ ，長さ $20 \mathrm{~mm} ， 34$ 本の矩形断面のマイクロチャンネルが隔壁幅 $260 \mu \mathrm{m}$ で造形されている．プレートを実 体顕微鏡で拡大した写真を図 3 に示寸，チャンネル幅および隔壁幅は，図 3(a)のようにマイクロ流路を拡大し， 十数か所で顕微鏡の測長機能（SMZ800, DS-Fi1/L2, 株式会社ニコン）で測定した值の平均值である. 流路深さ は，マイクロ流路部分の中央部で約 $2.5 \mathrm{~mm}$ 四方の正方形範囲にある 3 本の流路の面平均深さをレーザー顕微鏡 （OLS4100，オリンパス株式会社）で測定した．実験で用いた 19 枚のプレートの平均值は $198.82 \mu \mathrm{m}$ ，標準偏差 は $4.98 \mu \mathrm{m}$ であった. 他の部分の深さについては測定していないことと，この值がメーカーの公称值 $200 \mu \mathrm{m} に き$

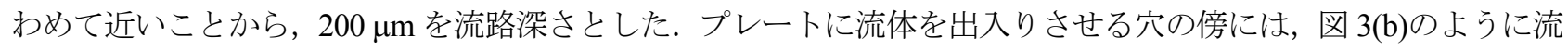




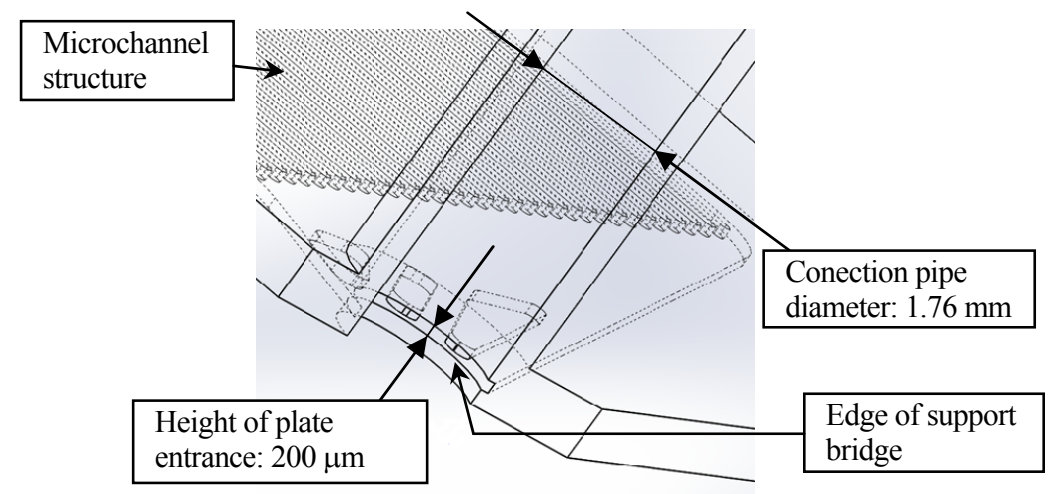

Fig. 5 Cut open view of the heat transfer plate entrance from the connection pipe. The entrance shape is semicircular slit on pipe wall with height of $200 \mu \mathrm{m}$ and angle of 180 degrees.

体をコアに均等に分配する/コアから流れてきた流体を穴に案内するためのサポートブリッジが設けられている. プレートの流路側の面に, 次のプレートの流路が造形されていない側の平らな面が重ねられることで，流路高さ は $200 \mu \mathrm{m}$ となる.

COMH 内には図 4(a)のように（高温流体／低温流体用の）２つの流路系が構成される. 流路系 1 (Conduit-system 1）を見ると，流体は上流側の接続管，エンドキャップ円板の穴，断熱板の穴を通過し，プレート積層部に到達す る. そこで 1 枚おきに伝熱プレートに分岐し，プレート出口で合流し，下流側の断熱板の穴，エンドキャップ円 板の穴，接続管を通過して熱交換器本体から流出する．接続管からプレートへの流体の出入口（図 4 の C, H) は, 図 5 の断面図が示すように幅 $200 \mu \mathrm{m}$ （=プレートの流路高さ）で, 図 3(b)の弧 A-B の部分が接続管断面円の 内角 180 度を占めるスリット状となる. 流路系 2 (Conduit-system 2) も図 4(a)の点線の矢印で示すように, 左右 対称となること以外は流路系 1 と全く同じ形状・寸法である.

本研究では熱交換が行われない場合の圧力損失を調べるため, 流路系 1，2 の一方のみに流体を流す．また， COMH には各流路系にそれぞれ 1〜10 枚までの任意の数のプレートを設置できるが, プレート枚数が 1 枚の場合 に限定して調べる．なぜならプレート枚数を複数とすると，図 4(a)のように各プレートに対する流体の分岐・合 流が生じる．このような複数流路への分岐および複数流路からの合流に関しては，合流部の容積や形状・枝管断 面のアスペクト比などが圧力損失に影響を与えることが報告されており(佐野他，2017), 損失係数が一般的な知 見として整備されていない状況にある. 本研究の目的は, プレートのコアに加え, サポートブリッジ，プレート の出入口，接続管を含めた熱交換器流路系の包括的な圧力損失予測方法を検討することであり，これに複数流路 への分岐・合流を含めると予測方法の妥当性を評価することが難しくなると考えたためである．プレート式熱交 換器ではプレート枚数を複数とすることもあり得るため, 複数流路への分岐・合流を含めた予測方法の確立は今 後の課題となる.

$\mathrm{COMH}$ 本体および伝熱プレートの寸法を表 1 にまとめた．表 1 には後の予測計算で使用する A〜J 地点の流路 断面積も記載した.

\section{$2 \cdot 2$ 陽的な圧力損失予測方法}

$\mathrm{COMH}$ 流路系は，接続管での管摩擦，プレート出入口での流路の曲がり・流路断面積の急縮小／拡大損失，コ アでの損失といった, 損失を伴う複数の流路要素で構成されている. 図6のような 1 つの流路要素に対して, 出 口の静圧が与えられたときに入口の静圧を予測する方法があれば, COMH 流路系全体にわたって要素 1 つずつに 予測を繰り返していき，流路系全体に対する予測を得ることができる，そこで1つの流路要素に対する予測方法 について検討する.

非圧縮性流れでは損失係数 $\zeta$ が既知であれば流路系の各要素の全圧損失 $\Delta p_{0}$ を次式で計算できる：

$$
\Delta p_{0}=\frac{1}{2} \zeta \bar{\rho} \bar{V}^{2}
$$


Table 1 Dimensions of the COMH conduit-system.

\begin{tabular}{|c|c|}
\hline Dimension & Remarks \\
\hline \multirow{2}{*}{\multicolumn{2}{|c|}{$\begin{array}{l}\text { Pipe friction section } \\
\text { (Connection pipe, end cap plate and insulation plate) }\end{array}$}} \\
\hline & \\
\hline \multicolumn{2}{|l|}{ Diameter $D_{\mathrm{p}}: 1.76 \mathrm{~mm}$} \\
\hline \multicolumn{2}{|l|}{ Total length $L_{\mathrm{p}}: 115 \mathrm{~mm}$} \\
\hline Cross-sectional area $A_{\mathrm{p}}: 2.43 \mathrm{~mm}^{2}$ & Cross-sectional area of A, B, I, J \\
\hline \multicolumn{2}{|l|}{ Heat transfer plate } \\
\hline \multicolumn{2}{|l|}{ Height of the conduit $h: 200 \mu \mathrm{m}$} \\
\hline \multicolumn{2}{|l|}{ Plate thickness : $0.5 \mathrm{~mm}$} \\
\hline \multicolumn{2}{|l|}{ - Core (Microchannels) } \\
\hline \multicolumn{2}{|l|}{ Channel width $w_{\mathrm{ch}}: 330 \mu \mathrm{m}$} \\
\hline \multicolumn{2}{|l|}{ Channel length $L_{\mathrm{ch}}: 20 \mathrm{~mm}$} \\
\hline \multicolumn{2}{|l|}{ Channel hydraulic diameter $D_{\mathrm{ch}}=2 h w_{\mathrm{ch}} /\left(h+w_{\mathrm{ch}}\right): 249 \mu \mathrm{m}$} \\
\hline \multicolumn{2}{|l|}{ Thickness of the partition wall $w_{\text {wall }}: 260 \mu \mathrm{m}$} \\
\hline \multicolumn{2}{|l|}{ Number of the channels $\quad N_{\mathrm{ch}}: 34$} \\
\hline \multicolumn{2}{|l|}{ Total channel width $w_{\text {core }}=N_{\mathrm{ch}} w_{\mathrm{ch}}: 11.2 \mathrm{~mm}$} \\
\hline Total channel cross-sectional area $A_{\text {core }}=w_{\text {core }} h: 2.24 \mathrm{~mm}^{2}$ & Cross-sectional area of E, $\mathrm{F}$ \\
\hline Core frontal width $w_{\mathrm{fr}}=N_{\mathrm{ch}} w_{\mathrm{ch}}+\left(N_{\mathrm{ch}}-1\right) w_{\text {wall }}: 19.8 \mathrm{~mm}$ & Fig. 2 \\
\hline \multicolumn{2}{|l|}{ Core frontal area $A_{\mathrm{fr}}=w_{\mathrm{fr}} h: 3.96 \mathrm{~mm}^{2}$} \\
\hline Cross-sectional area ratio $\sigma=A_{\text {core }} / A_{\text {fr }}: 0.57$ & Eq. (29) \\
\hline \multicolumn{2}{|l|}{ - Plate inlet/outlet (Fig.5) } \\
\hline Cross sectional area $A_{\mathrm{pl}}=\pi D_{\mathrm{p}} h / 2: 0.553 \mathrm{~mm}^{2}$ & Cross-sectional area of $\mathrm{C}, \mathrm{H}$ \\
\hline \multicolumn{2}{|l|}{ Support bridge (i is corresponding to Fig. 3(b)) } \\
\hline \multicolumn{2}{|l|}{ Conduit width $w_{\mathrm{sp}, \mathrm{i}}: 710 \mu \mathrm{m}, 590 \mu \mathrm{m}, 680 \mu \mathrm{m}, 510 \mu \mathrm{m}$} \\
\hline \multicolumn{2}{|l|}{ Conduit length $L_{\mathrm{sp}, \mathrm{i}}: 5.3 \mathrm{~mm}, 2.2 \mathrm{~mm}, 1.5 \mathrm{~mm}, 1.3 \mathrm{~mm}$} \\
\hline \multicolumn{2}{|l|}{ Total width $w_{\mathrm{sp}}=\sum w_{\mathrm{sp}, \mathrm{i}}: 2.49 \mathrm{~mm}$} \\
\hline Total cross-sectional area : $A_{\mathrm{sp}}=w_{\mathrm{sp}} h: 0.498 \mathrm{~mm}^{2}$ & Cross-sectional area of $\mathrm{D}, \mathrm{G}$ \\
\hline
\end{tabular}

ここで $\bar{\rho}, \bar{V}$ は参照密度，参照速度である。（非圧縮性流れの場合は密度が一定なので $\bar{\rho}=\rho$ である.）質量流 量が与えられれば寸法が既知の地点で速度を計算できるので，式(1)ですべての要素の全圧損失を計算することが でき，その総和として流路系全体の全圧損失を予測することができる.さらに全圧と静圧の間に

$$
p_{0}=p+\frac{1}{2} \rho V^{2}
$$

という関係が成り立ち, 各地点の全圧を求めることも容易である.

圧縮性流れでは損失によって圧力だけでなく速度・密度・静温度も同時に変化するが，最も簡単な予測方法と して例えば次に述べるものが考えられる. 図 6 の流路要素の入口を 1 , 出口を 2 とし, 質量流量, 貯気槽温度（流 路系に流入させる前の, 高圧のタンク内の速度 0 の気体の温度), 出口 2 の静圧 $p_{2}$ が与えられたとき, 1 におけ る静圧 $p_{1}$ を予測する．等温流を仮定して各地点の静温度は貯気槽温度に等しいものとする．状態方程式で 2 の 密度 $\rho_{2}$ が計算でき, 連続の式から速度 $V_{2}$ が計算できる.1-2 間で密度が一定であると仮定して, 連続の式を用 いて (面積比のみで) 入口 1 の速度の仮定值 $V_{1}{ }^{\prime}$ を得る. $V_{1}{ }^{\prime}, V_{2}$ からこの要素の参照速度 $\bar{V}$ を計算し, $\bar{\rho}=\rho_{2}$ と して式(1)で全圧損失 $\Delta p_{0}$ を計算する. 式(2)で出口の全圧 $p_{02}$ を計算し, $\Delta p_{0}$ を $p_{02}$ に加えて入口の全圧 $p_{01}$ と 


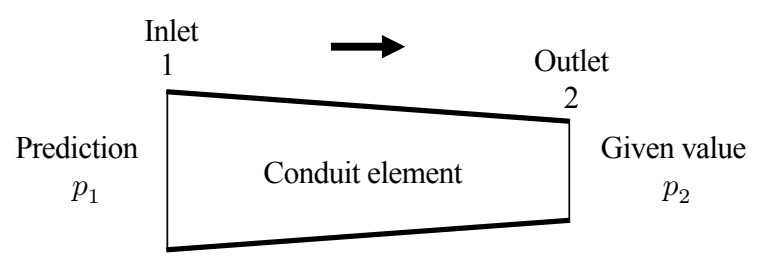

Fig. 6 Example of a conduit-element. Predicting inlet 1 states (like static pressure) by given outlet 2 states (or, vice versa) is the basics of prediction of a conduit-system which is composed of a number of elements.

し， $V_{1}{ }^{\prime}$ と式(2)によって $p_{1}$ の予測值を得る. $p_{1}$ から状態方程式で $\rho_{1}$ を計算し, 再び連続の式で $V_{1}$ を計算し て 1 の速度の予測值とする. これを上流の要素に繰り返して流路系全体の入口の静圧と速度を予測する. この方 法をMethod 1 とする.

この Method 1 は陽的に予測計算を進めることができ簡便であるという利点がある. その反面，等温流を仮定し ていること，要素を通過する流体の密度を一定と仮定していること， $V_{1}{ }^{\prime} \neq V_{1}$ であること，圧縮性流れに対して は成立しない式(1)，(2)を近似的に用いていること，という多くの近似が含まれている．これらは非圧縮性流れで あれば成立することがらであるが, 圧力の変化が大きく圧縮性の影響が無視できない流路要素では誤差が大きく なると考えられる，そこで，これらの近似を避けた予測方法を次節に述べる.

\section{$2 \cdot 31$ 次元断熱流れに基づく圧力損失予測方法}

図 6 の流路要素で質量流量, 貯気槽温度, 出口 2 の静圧 $p_{2}$ が与えられたとき, 要素の入口 1 の $p_{01}, V_{1}, p_{1}, \rho_{1}$, $T_{1}$ の予測を次のようにして行う.

断熱流れを仮定すると，圧縮性 1 次元流れのエネルギ式，連続の式および理想気体の状態方程式は次のように なる：

$$
\begin{aligned}
& T_{0}=\frac{V^{2}}{2 c_{p}}+T \\
& \dot{m}=\rho V A \\
& p=\rho R T
\end{aligned}
$$

式(3)〜(5)を解くことによって $p_{2}$ から $V_{2}, T_{2}$ を計算できる.

全圧は流れを等エントロピ的にせき止めたときの圧力で，次式で計算できる：

$$
\frac{p_{0}}{p}=\left(\frac{T_{0}}{T}\right)^{\frac{\kappa}{\kappa-1}}
$$

$p_{2}$ と $T_{2}$ を式(6)に代入して $p_{02}$ を計算できる. 流路要素を気体が流れる場合の全圧損失を, 非圧縮性流れの損 失係数を用いて近似的に式(1)で計算できるものと仮定する．この修正については次節で述べる.

断熱流れでは全温度（流れを等エントロピ的にせき止めたときの温度） $T_{0}$ は一定で，貯気槽温度と等しい. また，流路要素の密度，速度の参照値は

$$
\begin{aligned}
& \bar{V}=\bar{V}\left(V_{1}, V_{2}\right) \\
& \bar{\rho}=\frac{\dot{m}}{\bar{V} A}
\end{aligned}
$$

のように入口・出口の速度から計算されるものとし， $\bar{V}\left(V_{1}, V_{2}\right)$ の具体的な式の形を与えておく. このようにす ると式(1), (3) (6)は未知数が $p_{01}, V_{1}, p_{1}, \rho_{1}, T_{1}$ となるため, 数值的に解いて值を求めることができる. 式(1), (3)〜(6)は次の手順で解くことができる. 式(3)〜(5)を変形すると 


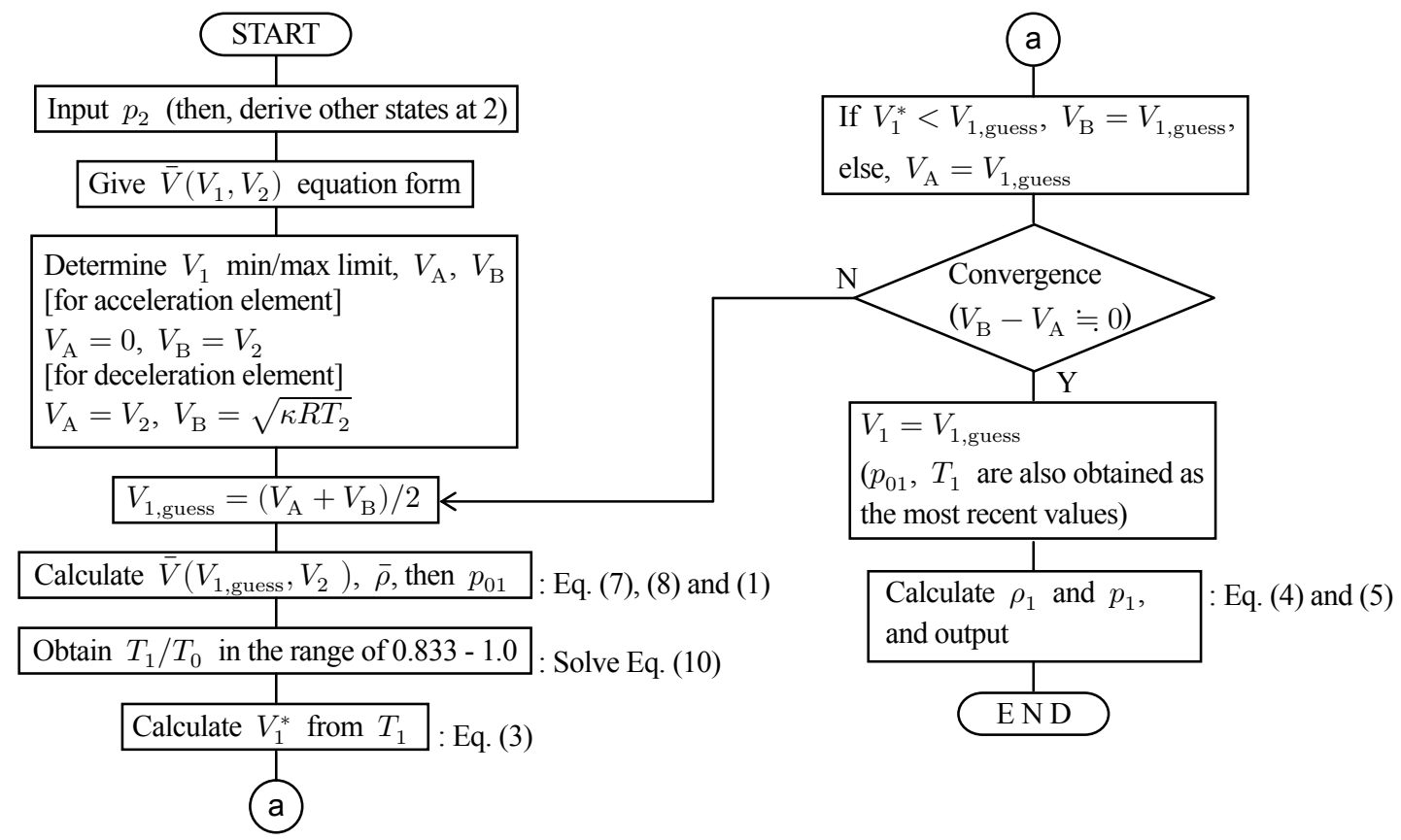

Fig. 7 Flowchart of solving the simultaneous equation of Eq. (1) and (3) - (6). Equation (1) can be replaced by Eq. (16) and (17) for pressure loss calculation based on heat generation by dissipation as described in section 2.4.

$$
p=\frac{\dot{m} R T}{A \sqrt{2 c_{p}\left(T_{0}-T\right)}}
$$

となり, $p$ を $T$ のみで表すことができる.これを式(6)に代入して整理すると

$$
p_{0}=\frac{\dot{m} R \sqrt{T_{0}}}{A \sqrt{2 c_{p}}}\left(\frac{T}{T_{0}}\right)^{-\frac{\kappa}{\kappa-1}}\left(1-\frac{T}{T_{0}}\right)^{-\frac{1}{2}}
$$

が得られる. $V_{1}$ の最小值を $V_{\mathrm{A}}$, 最大值を $V_{\mathrm{B}}$ として, 流れが加速する要素では $V_{\mathrm{A}}=0, V_{\mathrm{B}}=V_{2}$, 減速する 要素では $V_{\mathrm{A}}=V_{2}, V_{\mathrm{B}}$ =音速 を与える. $V_{1}$ の暫定值として $V_{1, \text { guess }}=\left(V_{\mathrm{A}}+V_{\mathrm{B}}\right) / 2$ とする. 式(7), (8)で $\bar{V}$, $\bar{\rho}$ を計算する．式(1)より $\Delta p_{0}$ が計算され， $p_{01}$ が得られる．流れが亜音速の範囲にあるとし，式(10)を 2 分法で 解いて 0.833 (マッ八数 $M a=1) \sim 1 （ M a=0 ）$ の範囲にある解 $T_{1} / T_{0}$ を求め, $T_{1}$ が得られる. $T_{1}$ を式(3) に代入して $V_{1}^{*}$ を計算し， $V_{1, \text { guess }}$ との差を見て，2 分法により $V_{\mathrm{A}}$ または $V_{\mathrm{B}}$ の值を更新する. これを $V_{1}^{*}$ が収 束するまで繰り返し, 収束した值を $V_{1}$ の予測值とする. これにより $V_{1}, T_{1}, p_{01}$ の予測值が確定するので, 式(4), (5)によって $\rho_{1}, p_{1}$ の予測が得られる. この手順をフローチャートにまとめると図 7 のようになる. 以上, 本節で述べた方法を Method 2 とする.

Method 2 は式(10)を数值的に解かなければならないため解法プログラム作成の点でMethod 1 よりも手間がかか るが，式(1)を用いていること，等温流を仮定する代わりに断熱流を仮定していること以外は 2.2 節の最後に述心゙ た近似を用いておらず，予測方法の理論的根拠が高められていると考えられる. また, Method 2 で行われる計算 は式(1), (3)〜(6)の代数的な連立方程式を解くことだけなので, 例えばNS 方程式を数值的に解く通常の流れのシ ミュレーションと比べて計算の量はきわめて少ない. 実際, 図 7 のフローチャート中の収束判定基準を $10^{-9}$ とし て PC (CPU : Intel Core i7-4770K，3.50GHz) で予測計算プログラムを実行したところ, 要した時間は $0.06 \mathrm{~s} \sim 0.07$ sであり，短時間で予測を行うことができる.

\section{$2 \cdot 4$ 全圧損失計算の修正}

全圧損失を非圧縮性流れの式(1)で近似せず，圧縮性を考慮して計算する方法を本節で提案する. 


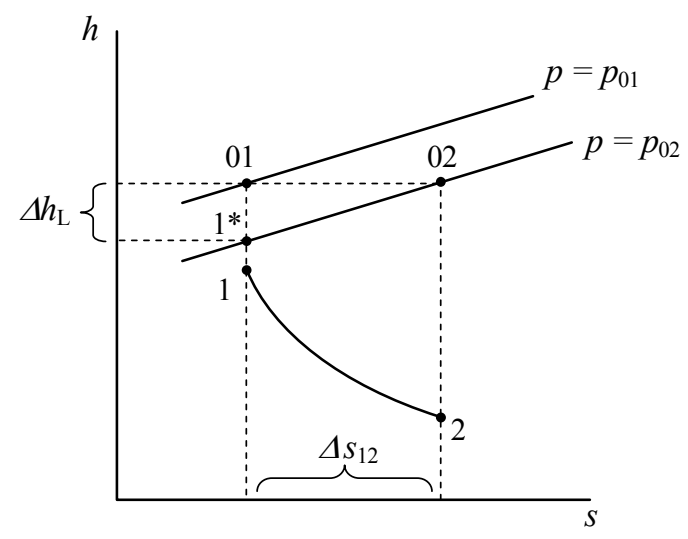

(a) Incompressible flow

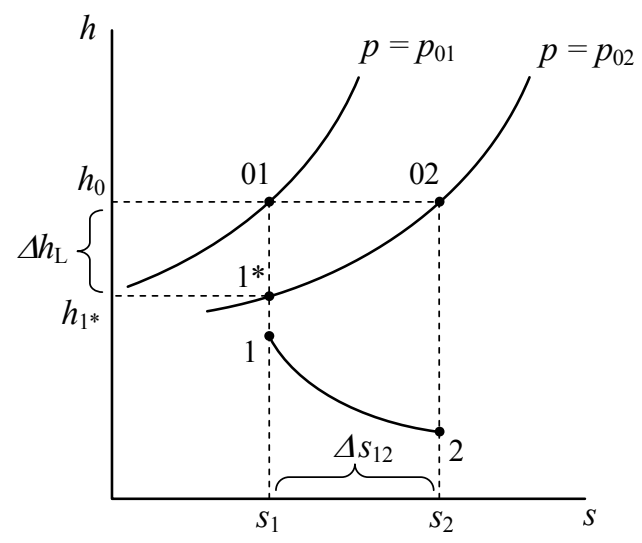

(b) Compressible flow

Fig. 8 Interpretation of pressure loss on h-s chart. Total pressure loss is pressure difference between 01 and 02 . The value of pressure loss is pressure drop when 01 is isentropically accelerated as enthalpy decreases by $\Delta h_{\mathrm{L}} . \Delta h_{\mathrm{L}}$ can be calculated using entropy increase $\Delta s_{12}$ if isobaric curve's equation is known. $\Delta s_{12}$ is calculated from internal heat generation by dissipation, $q_{12}$. For incompressible flow, $q_{12}$ is obtained by Eq. (12). So, assuming Eq. (12) for compressible flow and selecting proper reference temperature, $\Delta h_{\mathrm{L}}$ is obtained as Eq. (16) for compressible flow, then $p_{02}=p_{1^{*}}$ is obtained by isentropic flow correlation, Eq. (17).

非圧縮性断熱流れの場合, 流路要素の入口 1 と出口 2 の間の 1 次元流れのエネルギ式

$$
\frac{1}{2} \rho V_{1}^{2}+p_{1}+c \rho T_{1}=\frac{1}{2} \rho V_{2}^{2}+p_{2}+c \rho T_{2} \quad\left(\Longleftrightarrow \frac{1}{2} V_{1}^{2}+h_{1}=\frac{1}{2} V_{2}^{2}+h_{2}\right)
$$

（ c は流体の比熱）と式(1)，(2)より，

$$
q_{12}=c\left(T_{2}-T_{1}\right)=\frac{\Delta p_{0}}{\rho}=\zeta \frac{1}{2} \bar{V}^{2}
$$

が得られ，散逸による流体の単位質量当たりの発熱量 $q_{12}$ に密度を乗じたものが全圧損失であることが分かる. $q_{12}$ が式(12)のように与えられたとき，1-2 間でエネルギ式を立てることなく式(1)を導くことができる.（この 考察を述べる理由は，圧縮性流れの場合はエネルギ式を変形することで $q_{12}$ と全圧損失を結び付けられないから である.）例えば水の場合， $c \rho \approx 10^{6}\left[\mathrm{~J} /\left(\mathrm{m}^{3} \cdot \mathrm{K}\right)\right]$ で， $100 \mathrm{kPa}$ の全圧損失が $0.1 \mathrm{~K}$ の温度上昇に相当するから，温度 を一定とみなせる. エントロピの定義

$$
d s=\frac{d h-d p / \rho}{T}
$$

より, h-s 線図上での等圧線は $d h=T d s$ である. よって $T$ が一定であれば h-s 線図上で等圧線は傾きが $T$ の直 線となる. 図 8(a)は, 非圧縮性流体が流路要素の入口 1 から出口 2 まで流れる場合の, 入口での状態 1 , 出口で の状態 2 , 入口・出口でのよどみ点状態 01,02 を h-s 線図上に示したものである. 曲線 1-2 は入口から出口まで の流体の実際の状態変化を表す.この曲線 1-2 は流れが加速する $V_{1}<V_{2}$ の場合, すなわち式(11)より $h_{1}>h_{2}$ と なる場合を例示したものである．式(11)のように，断熱流れでも速度が変化すればエンタルピは変化する．流れ の速度が変化しない場合は $h_{1}=h_{2}$, 減速する場合は $h_{2}>h_{1}$ の曲線となる(妹尾, 1995). どの場合でも以降の 議論に変わりはない. この図より, 全圧損失 $\Delta p_{0}=p_{01}-p_{02}$ は, よどみ点状態 01 から等エントロピ的に（摩 擦のないノズルなどを用いて仮想的に） $\Delta h_{\mathrm{L}}=T \Delta s_{12}$ だけエンタルピが減少するように流れを加速させた場合 の圧力降下量 $p_{01}-p_{1 *}$ に等しいということが分かる. $\Delta h_{\mathrm{L}}$ と $p_{01}-p_{1 *}$ の具体的な関係は $(h=p / \rho+c T よ り)$

$$
\Delta h_{\mathrm{L}}=\frac{p_{01}-p_{1 *}}{\rho}
$$

である.以上より 


$$
\Delta p_{0}=p_{01}-p_{02}=p_{01}-p_{1 *}=\rho \Delta h_{\mathrm{L}}=\rho T \Delta s_{12}=\rho q_{12}
$$

となり，これに式(12)を代入すると式(1)の全圧損失の式に一致する.

圧縮性流れの場合に， $q_{12}$ が非圧縮性流れの損失係数を用いて近似できると仮定する. 図 8(b)は圧縮性流体が流 路要素の入口 1 から出口 2 まで流れる場合に, 図 8(a) と同様の h-s 線図を示したものである. $p_{02}$ を求めるため に，まず $\Delta h_{\mathrm{L}}$ を知る必要がある．圧縮性流体の場合の等圧線の式 $d h=T d s$ は， $h=c_{p} T$ であることを用いる と $h=C e^{\frac{s}{c_{p}}}$ (Cは積分定数) となる. これは $h=e^{\frac{s}{c_{p}}+\log C}$ と变形できるので, $\mathrm{h}-\mathrm{s}$ 線図上で圧縮性流体の等圧線

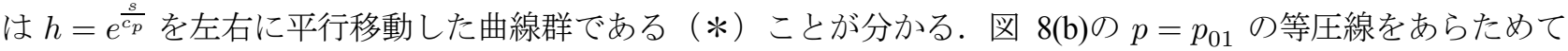
$h=C e^{\frac{s}{c_{p}}}$ とおく，この曲線上で $h$ が全エンタルピ $h_{0}=c_{\mathrm{p}} T_{0}$ となるときのエントロピを $s_{1}$ とおく: $h_{0}=C e^{\frac{s_{1}}{c_{p}}}$. (*) により, $h_{1 *}=C e^{\frac{s_{1}-\Delta s_{12}}{c_{p}}}$ とおけるから, $h_{1 *} / h_{0}=e^{\frac{s_{1}-\Delta s_{12}}{c_{p}}-\frac{s_{1}}{c_{p}}}=e^{\frac{-\Delta s_{12}}{c_{p}}}$. よって, この流路 要素での参照温度 $\bar{T}$ を用いて $\Delta s_{12}=q_{12} / \bar{T}$ と近似すれば，仮定より式(12)を用いて

$$
\Delta h_{\mathrm{L}}=h_{0}\left(1-\frac{h_{1 *}}{h_{0}}\right)=h_{0}\left\{1-\exp \left(-\frac{\zeta}{2 c_{p} \bar{T}} \bar{V}^{2}\right)\right\}
$$

によって $\Delta h_{\mathrm{L}}$ を計算することができる.これによって $T_{1 *}=T_{0}-\Delta h_{\mathrm{L}} / c_{\mathrm{p}}$ を知ることができる. $p_{02}=p_{1 *}$ で あり，01 と $1 *$ *同じ等エントロピ線上にあるから，等エントロピ変化の式(6)を用いて

$$
p_{02}=p_{01}\left(\frac{T_{1 *}}{T_{0}}\right)^{\frac{\kappa}{\kappa-1}}
$$

として，1の全圧 $p_{01}$ から 2 の全圧 $p_{02}$ を計算することができる（式(17)を $p_{01}$ について解けば 2 の全圧から 1 の全圧を計算することもできる.）

これを用いて実際に予測計算を行うには, 図7 のフローチャートで式(1)を式(16), (17)に変えればよい. エント ロピ増加の計算に必要な $\bar{T}$ は各要素の $\bar{V}$ と式(3)で計算する. この方法を Method 3 とする.

式(16), (17)の導出で用いたのは, 圧縮性流れの散逸による発熱量と速度の関係が非圧縮性流れと同じとみなせ る, という仮定である.これに対し式(1)を圧縮性流れに用いるのは，本来非圧縮性流れにしか成り立たない関係 式で近似を行う，ということである．前者の方が仮定の物理的な意味が明快であり，後述のように実験結果との 一致も Method 1 3 の中で最も良いため, 妥当性は高いと考える. 予測計算に要する時間は Method 2 と変わらな い.

\section{$2 \cdot 5$ 各流路要素の損失係数および密度 $\cdot$ 速度の参照値}

圧力損失の予測を行うにあたり, $\mathrm{COMH}$ 流路系を流路要素に分割し, 各要素ごとに式(1)の損失係数 $\zeta$ の值お よび式(7)の $\bar{V}\left(V_{1}, V_{2}\right)$ の具体形を与える必要がある.

$\mathrm{COMH}$ 流路系を図 4(a)の A〜J に示寸地点で分け, 各地点間の 9 つの区間を流路要素でモデル化し, 損失係数 を定める．モデル化の概略を図 4(b)に示す．本節で別の出典の記載なしに引用されている損失係数は，すべて非 圧縮性流体の技術資料(管路・ダクトの流体抵抗出版分科会, 1979)に掲載されているものである. その他の本文 中の定数は表 1 に值を示している.

添字 1,2 は流路要素の入口, 出口を表す. 参照速度については, 以下で別の指定がない流路要素では入口・出 口の平均速度

$$
\bar{V}=\frac{V_{1}+V_{2}}{2}
$$

を用いている.

摩擦損失が作用する区間では，損失係数はダルシーの摩擦係数 $\lambda$ を用いて

$$
\zeta=\lambda \frac{L}{D}
$$


と表される.入の算出に必要なレイノルズ数は

$$
R e=\frac{\bar{\rho} \bar{V} D}{\mu}
$$

と表される。

A-B 間および I-J 間は円形断面の接続管・エンドキャップ円板の穴・断熱板の穴からなる流路で, 直径 $D_{\mathrm{p}}$, 長さ $L_{\mathrm{p}}$ の円管となる. この区間では $D=D_{\mathrm{p}}, L=L_{\mathrm{p}}$, および

$$
\lambda=\left\{\begin{array}{cc}
64 / R e & (R e<2300) \\
0.316 / R e^{0.25} & (R e \geqq 2300)
\end{array}\right.
$$

として，式(19)で損失係数を計算する.

B-C 間, H-I 間は接続管とプレートの出入口である. B-C 間は断面積 $A_{\mathrm{p}}$ の接続管の流れがプレート入口断面積 $A_{\mathrm{pl}}$ に急縮小し, その後 $90^{\circ}$ 曲がると近似した. $A_{\mathrm{pl}} / A_{\mathrm{p}}$ が 0.23 となるから, 急縮小部は損失係数は 0.38 とし た. 流路が曲がることによる損失では, $90^{\circ}$ エルボの理論值(西，1993)の損失係数 1.0 を用いた. このようにする と参照速度がともに要素出口側の速度となるので

$$
\begin{aligned}
& \bar{V}=V_{2} \\
& \zeta \fallingdotseq 0.38+1.0=1.38
\end{aligned}
$$

である. H-I 間はプレート出口断面積 $A_{\mathrm{pl}}$ の流れが $90^{\circ}$ 曲がり，その後接続管の断面積 $A_{\mathrm{p}}$ に急拡大すると近似 した. 曲がる際の損失係数は同様に 1.0 とし, 急拡大部の損失係数は $\left(1-A_{\mathrm{pl}} / A_{\mathrm{p}}\right)^{2}=0.59$ となる. 参照速度は ともに要素入口側の速度となるので

$$
\begin{aligned}
& \bar{V}=V_{1} \\
& \zeta \fallingdotseq 1.0+0.59=1.59
\end{aligned}
$$

である。

C-D 間および G-H 間は伝熱プレートのサポートブリッジ部（図 3(b)）である。この部分は異なる長さ・幅の 4 本の流路に分かれるが, 簡単のため, 寸法を平均值とする 4 つの矩形流路に等分配されるとして, 式(19)で損失 係数を計算する. もとの 4 本の流路のコア側の幅の和を $w_{\mathrm{sp}}$ とするとき，寸法を平均值とする流路のコア側の幅 は $w_{\mathrm{sp}} / 4$, プレート出入口側の幅は $A_{\mathrm{pl}} /(4 h)$, 長さは $L=\sum L_{\mathrm{sp}, \mathrm{i}} / 4$ として, 流路幅は直線的に変化するもの とし, 中央の地点での摩擦係数を用いる. 臨界レイノルズ数は円管の 2300 を用いた. 矩形流路の層流の管摩擦係 数は $\bar{w}$ と の比より決定した(Shah and London, 1978) :

$$
\begin{aligned}
& \bar{w}=\frac{1}{2}\left(\frac{w_{\mathrm{sp}}}{4}+\frac{A_{\mathrm{pl}}}{4 h}\right), \quad D=\frac{4 \bar{w} h}{2(\bar{w}+h)} \\
& \lambda=\left\{\begin{array}{cc}
70.6 / R e & (R e<2300) \\
0.316 / R e^{0.25} & (R e \geqq 2300)
\end{array}\right.
\end{aligned}
$$

D-E 間および F-G 間はサポートブリッジとコア間の流路で，コア部分の幅を $w_{\mathrm{fr}}$ (図 2）として流路長さ $L=w_{\mathrm{fr}} / 2$, 流路幅はブリッジ側の $w_{\mathrm{sp}}$ からコア側の $w_{\mathrm{core}}$ に直線的に変化するとした. この部分は高さに比べ 幅が大きくなるので, 平行平板の摩擦損失が作用すると近似した. $D=2 h$ として式(19)で損失係数を計算する：

$$
\lambda=\left\{\begin{array}{cc}
96 / R e & (R e<3560) \\
0.316 / R e^{0.25} & (R e \geqq 3560)
\end{array}\right.
$$

D-E 間では流れ方向に流路断面積が拡大寸るため, サポートブリッジ出口のエッジの部分等で剥離が生じる可能 性があるが，本論文ではこの影響は考慮せず，摩擦損失のみが作用すると近似してモデル化した. 
E-F 間は熱交換器コアとなる伝熱プレートのマイクロチャンネル部分である. Kays らの提案した方法(Kays and London, 1984)によると, コアの圧力損失は入口損失・チャンネル摩擦損失・出口損失からなり, 損失係数は

$$
\zeta=\left(1-\sigma^{2}+K_{\mathrm{c}}\right)+4 f \frac{L_{\mathrm{ch}}}{D_{\mathrm{ch}}}-\left(1-\sigma^{2}+K_{\mathrm{e}}\right)
$$

となる. ここで $\sigma=0.57$ はコアの流路断面積 $A_{\text {core }}$ （=チャンネル本数 $\times 1$ 本のチャンネル面積）のコア前面面 積 $A_{\mathrm{fr}}$ に対する比で，プレートの寸法より算出する. $K_{\mathrm{c}}=1.06, K_{\mathrm{e}}=-0.257$ はそれぞれコアの入口収縮損失 係数, 出口拡大損失係数で, $\sigma$ の值に対して Kays らの文献に記載された線図より読み取った值である. $f$ はファ ニング摩擦係数で, 1 本のチャンネルの幅・深さの比より $f \cdot R e=15.0$ (Shah and London, 1978)となる.レイノル ズ数は $D=D_{\mathrm{ch}}$ として計算する.

予測手法をできるだけ簡単に定式化するため，摩擦損失の計算では式(21)，(27)，(28)のように層流から乱流の 遷移域は考慮しておらず，臨界レイノルズ数を境に層流と乱流の損失係数が切り替わるものと扱った。したがっ て，遷移域の損失係数が乱流のもので近似されることになり，その分だけ実際よりも大きな損失が計算されると 考えられる. 表 2 に，本研究の実験条件下における摩擦損失を伴う流路要素のレイノルズ数を示す．接続管・サ ポートブリッジの遷移域を $2300<R e<4000$ とし，サポートブリッジとコア間の流路では臨界レイノルズ数 $R e=3560$ を超えた直後は遷移域であると考え, 表 2 で遷移域に該当するレイノルズ数に記号( Tr)を付した. ま た $(\mathrm{Tr})$ を付した要素に起こる圧力損失の（4 章の\#5 による）予測值が，熱交換器全体の予測圧力損失のうちに占 める割合も表 2 に示した. 遷移域となる流路要素は各質量流量に対して多くても一種類であり, 予測圧力損失全

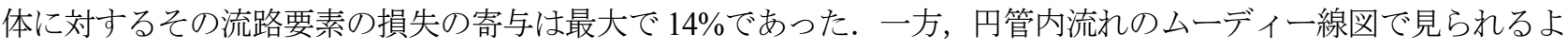
うに，遷移域の損失係数が式(21), (27), (28)の層流の式・乱流の式の中間の值をとると考え, これらの式に臨界 レイノルズ数を代入して比をとることによって, 遷移域の損失係数を乱流の損失係数で近似すると損失係数を最 大で 1.6 倍大きく見積もる可能性があることが分かる. したがって, 遷移域を乱流で近似することにより，全体 の予測圧力損失は最大で $5 \%$ 程度（=14\%-14\%⒈6）大きく計算されることがあると考えられる.

Table 2 Reynolds number in each conduit-element.

\begin{tabular}{c|c|c|c|c}
\hline \hline \multirow{2}{*}{$\begin{array}{c}\text { Mass flow rate } \\
\dot{m}[\mathrm{~kg} / \mathrm{s}] \\
\times 10^{-5}\end{array}$} & $\begin{array}{c}\text { Reynolds number of conduit-element with friction loss (conduit-element in Fig. 4) } \\
\text { (E-F) }\end{array}$ & $\begin{array}{c}\text { Connection pipe } \\
\text { (A-B and I-J) }\end{array}$ & $\begin{array}{c}\text { Support bridge } \\
\text { (C-D and G-H) }\end{array}$ & $\begin{array}{c}\text { Conduit from bridge to channel } \\
\text { (D-E and F-G) }\end{array}$ \\
\cline { 2 - 5 } 6.149 & 371 & $2420(\mathrm{Tr},(\mathrm{i}))$ & 1950 & 974 \\
12.19 & 734 & 4790 & $3860(\mathrm{Tr},(\mathrm{ii}))$ & 1930 \\
16.23 & 978 & 6370 & 5140 & 2570 \\
20.24 & 1220 & 7950 & 6410 & 3210 \\
24.18 & 1460 & 9500 & 7660 & 3830 (Tr, (iii)) \\
\hline \hline
\end{tabular}

(Tr) : Transition flow regime

\section{3. 実験方法}

2.1 節で述べた COMH の実機に対して実験を行った．実験装置系統図を図 9(a)に示寸．大気圧の実験室内の空 気をコンプレッサ（ACP-13SLA，株式会社高儀）で圧縮し，エア一乾燥管（3001-17111，ジーエルサイエンス株 式会社), 流量制御バルブ (2412T, コフロック株式会社), 流量計 (CMS0050, アズビル株式会社), 圧力・温度 測定部を介して接続管端部より COMH の流路系 1 または 2 (図 4(a)の Conduit-system 1 または 2) に流入させる. 空気は COMH を通過後, 圧力・温度測定部を通過して実験室内に流出する.

圧力・温度測定部は図 9(b)のような構成となっている. 直径 $8 \mathrm{~mm}$, 長さ $150 \mathrm{~mm}$ の円管流路の一端から $25 \mathrm{~mm}$ の位置に直径 $0.5 \mathrm{~mm}$ の小孔をあけ, 圧力センサ（VESX-500, 株式会社バルコム）を接続する. 他端から $25 \mathrm{~mm}$ 


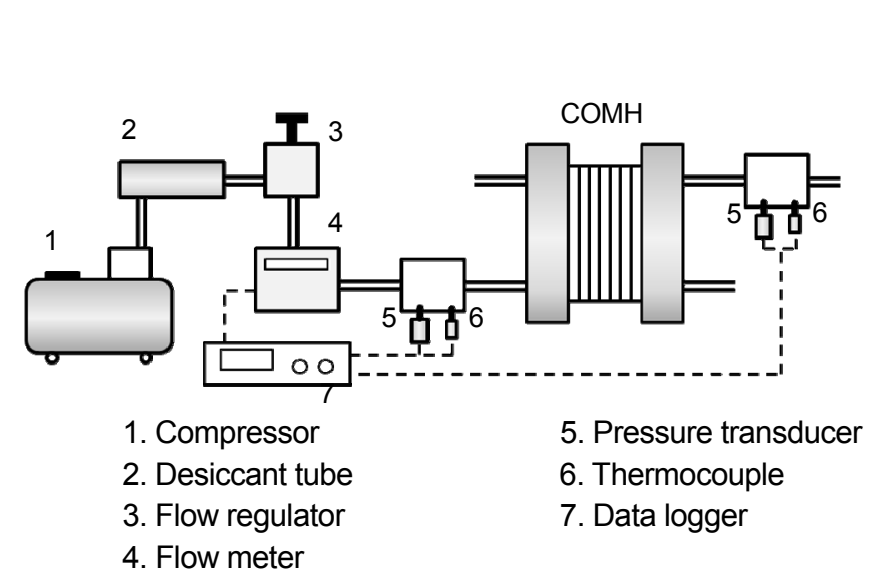

(a) Experimental setup.

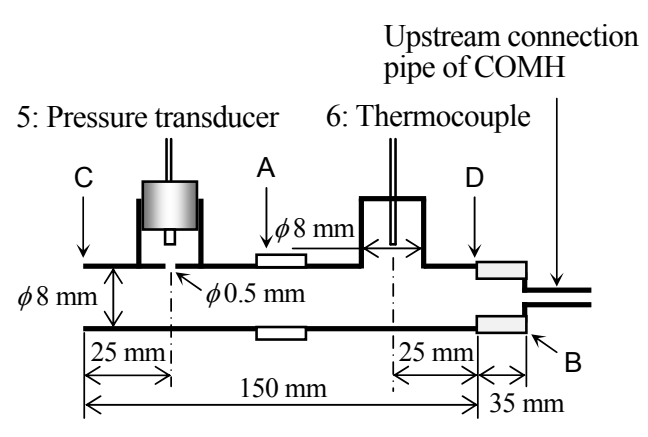

\begin{abstract}
A: Pipe joint B: Connector (inner diameter : $8 \mathrm{~mm}$ ) (inner diameter : $4.8 \mathrm{~mm}$ ) C, D: Edge of the measurement section
\end{abstract}

(b) Schematic diagram of measurement section.

Fig. 9 Schematic diagrams of experimental setup and pressure/temperature measurement section.

の位置に直径 $8 \mathrm{~mm}$ の温度測定部を設け, $\mathrm{T}$ 型熱電対を挿入する. 測定部中央には内径 $8 \mathrm{~mm}$ のねじ込み継手 $(6 \mathrm{~N}$. 呼び径 B: $1 / 4$ ，オーエヌ工業株式会社）による接続部がある。この測定部の熱電対側 D と COMH 上流側接続管を コネクタ（DCT-2-R4-SS, イハラサイエンス株式会社）で接続する. COMH 下流側では圧力センサ側 C と接続し, $\mathrm{D}$ は実験室に開放する。このようにすると圧力は測定部の内径 $8 \mathrm{~mm}$ 円管内流れの静圧を測定していることにな るが，下流側では測定部の $\rho V^{2} / 2$ が最大で $10 \mathrm{~Pa}$ と見積もられるため, 測定部での損失は無視でき，この圧力を 接続管出口の静圧とみな寸ことができる.上流側は, 測定部および接続管入口の $\rho V^{2} / 2$ の最大值がそれぞれ $3 \mathrm{~Pa}$, $1.2 \mathrm{kPa}$ と見積もられるので, 測定部の損失は無視でき, また接続管入口での動圧への変換分を近似的に無視する ことにより，測定值を接続管入口の静圧と扱うことにする.

流量計, 圧力センサ, 熱電対はデータロガー（CADAC21, 江藤電機株式会社）に接続し, PC で測定值を監視, 記録する. コンプレッサの圧力調整器およびバルブによって目標の質量流量になるように流量を調整し，定常状 態となったところで 1 秒間隔で 10 回記録を行い，その平均值を測定值とした.

$\mathrm{COMH}$ 流路系には 1 枚の伝熱プレートを設置する. COMH 流路系 1 と 2 のそれぞれに（左右対称であること 以外は）同一形状の伝熱プレートを 10 枚，9枚用意し，その 1 枚ずつに実験を繰り返し，全 19 枚のプレートに 対するデータを平均して実験值とした.

動作流体となる実験室の空気は, ガス定数 $287.03 \mathrm{~J} /(\mathrm{kg} \cdot \mathrm{K}$ ), 比熱比 1.4 である(日本機械学会, 2006). このとき 定圧比熱は $1005 \mathrm{~J} /(\mathrm{kg} \cdot \mathrm{K})$ となる. 粘度 $\mu$ は実験時の温度からサザランドの式で計算し， $\mu=1.842 \times 10^{-5} \mathrm{~Pa} \cdot \mathrm{s}$ で ある.

\section{4. 圧力損失予測と実験結果の比較，考察}

\section{$4 \cdot 1$ 圧力損失予測と実験結果の比較}

実験で測定された質量流量, チャンネル内レイノルズ数, COMH 接続管入口 A および出口 J の静圧を表 3 に示

Table 3 Experimental results and predicted Mach number at microchannel outlet.

\begin{tabular}{c|c|c|c|c|c}
\hline \hline \multirow{2}{*}{$\begin{array}{c}\text { Mass flow } \\
\text { rate } \\
\dot{m} \begin{array}{c}{[\mathrm{kg} / \mathrm{s}]} \\
\times 10^{-5}\end{array}\end{array}$} & $\begin{array}{c}\text { Channel } \\
\text { Reynolds } \\
\text { number }\end{array}$ & $\begin{array}{c}\text { COMH inlet } \\
\text { (A in Fig. 4) }\end{array}$ & $\begin{array}{c}\text { COMH outlet } \\
\text { (J in Fig. 4) }\end{array}$ & Difference (Scattering of data) & $\begin{array}{c}\text { Channel outlet } \\
\text { Mach number by } \# 5 \\
\text { in Fig. 4) } \\
\text { prediction }\end{array}$ \\
\hline 6.149 & 371 & 132 & 99.4 & $32.6(-16.1 \%-+16.5 \%)$ & 0.0583 \\
12.19 & 734 & 191 & 99.4 & $91.6(-14.8 \%-+14.9 \%)$ & 0.0897 \\
16.23 & 978 & 239 & 99.4 & $140(-16.6 \%-+13.9 \%)$ & 0.101 \\
20.24 & 1220 & 290 & 99.4 & $191(-15.2 \%-+15.4 \%)$ & 0.108 \\
24.18 & 1460 & 341 & 99.4 & $242(-14.6 \%-+12.7 \%)$ & 0.112 \\
\hline \hline
\end{tabular}




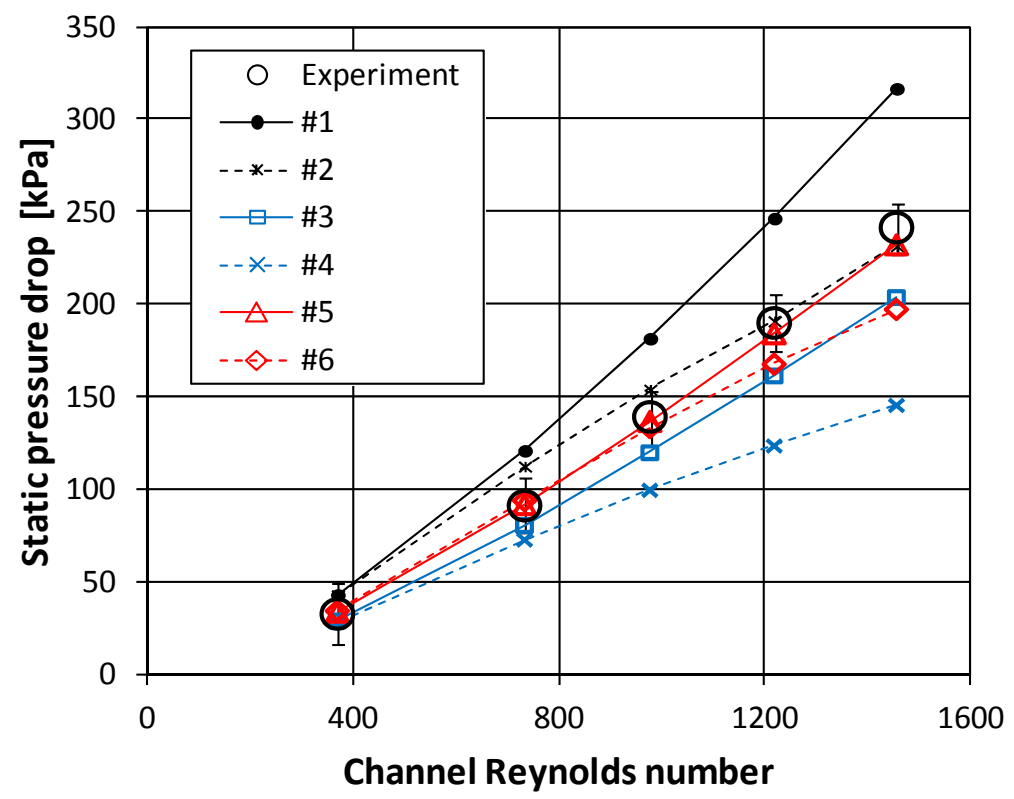

(a) Static pressure drop between A and J in Fig. 4.

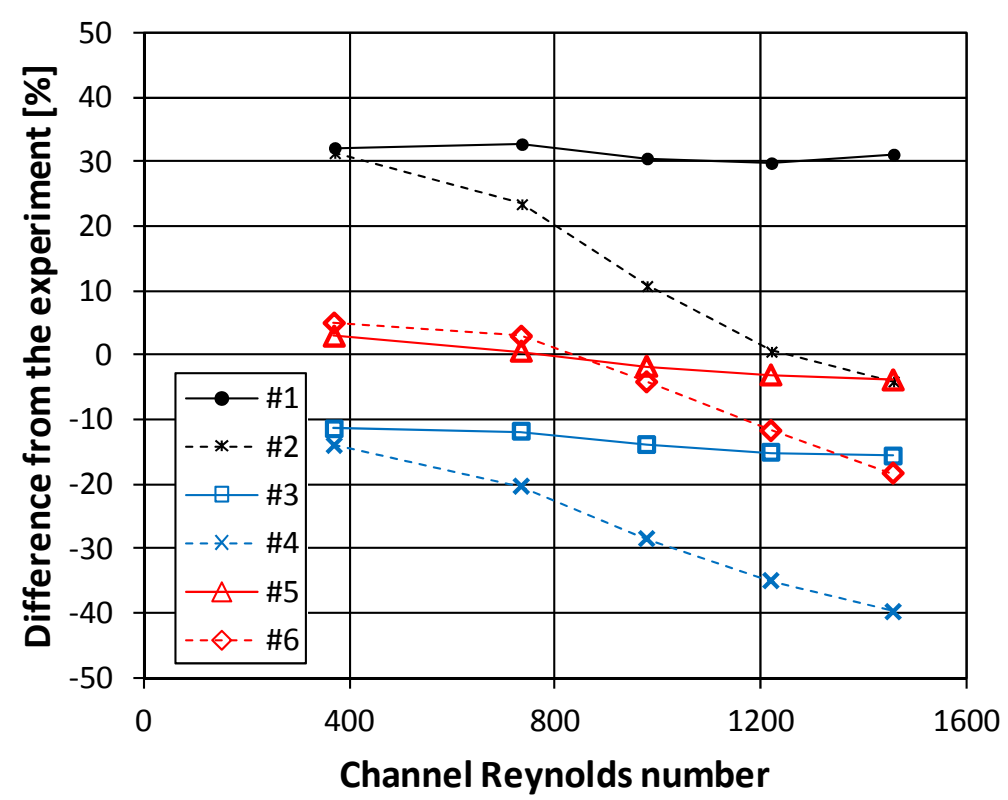

(b) Difference of static pressure drop between the predictions and the experiment.

Fig. 10 The experimental and predicted static pressure drop between A and J (in Fig. 4) is shown in (a). The difference of the predictions from the experiment in (a) is shown in (b). \#1 and \#2 are the prediction method 1 (in section 2.2), where isothermal flow and constant densities in each conduit-element are assumed. \#3 and \#4 are the method 2 (in section 2.3), which solves the simultaneous equation of one-dimensional adiabatic flow by the process shown in Fig. 7, while still assuming incompressible pressure drop correlation (Eq. (1)). \#5 and \#6 are the method 3 (in section 2.4), which is the same as method 2 except for using modified pressure loss correlation of Eq. (16) and (17). \#1, \#3 and \#5 (solid lines) predict static pressure at inlet A by given outlet $\mathrm{J}$ state. \#2, \#4 and \#6 (dashed lines) are vice versa. As shown in (b), the method 1 has $30 \%$ difference from the experiment due to many approximations in formulation. \#3 has the difference of $-16 \%$ to $-11 \%$, and the best prediction $\# 5$ has the difference of $-3.9 \%$ to $2.9 \%$. It can be seen that using the higher pressure inlet states as initial value of prediction expands difference from the experiment (\#4 and \#6).

す.また, チャンネル出口 $\mathrm{F}$ での (後述の\#5 による) 予測マッハ数を表 3 に示す.レイノルズ数は式 $(20) て ゙ ~ D=D$ ch として計算した. $R e=\dot{m} D_{\mathrm{ch}} /\left(\mu A_{\text {core }}\right)$ となるため, レイノルズ数は質量流量に比例する. チャンネル出ロの予 測マッ八数は $0.0583 \sim 0.112$ の範囲で, チャンネル内の流れに対しては圧縮性の影響は小さいと考えられる. 接続 管入口・出口の測定静圧の差は $32.6 \mathrm{kPa} \sim 242 \mathrm{kPa}$ となり, レイノルズ数の増加に伴って圧力差が上昇している. 


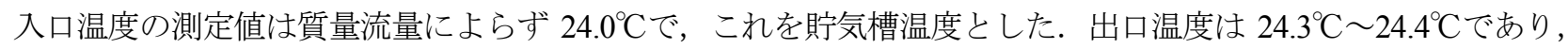
入口温度との差は小さく, Method 2, 3 の断熱流れの仮定は本実験条件下では適切と考えられる.

表 3 の質量流量に対して接続管入口・出口の静圧の差の予測を行った結果を図 10 に示寸. 図 $10(\mathrm{a})$ は圧力差の 実験值と予測值，図 10(b)は予測結果の実験值に対する差（(予測結果一実験值）－実験值 [\%]）である. 図 10(a) の実験值のエラーバーは各プレートの実験值が存在する範囲を示し, 具体的な数值は表 3 に示している. 圧力差 の実験值にはプレート毎に平均值から $17 \%$ 程度の差が見られた. 各プレートの流路深さの測定值が平均值から $-7 \mu \mathrm{m} \sim+10 \mu \mathrm{m}$ の範囲にあったことから，エッチングによる造形の際にプレート毎に多少の寸法差が生じ，測定 された圧力差のばらつきにつながったと考えられる，質量流量は目標の值に調整しているためばらつきの範囲は $-2.1 \% \sim+2.5 \%$ （ $R e=371$ のときのみ～+5.2\%） と小さく, 図 10(a)では横軸方向のエラーバーを省略した. 図 10 の\#1，\#2 はMethod 1，\#3，\#4 は Method 2, \#5, \#6 は Method 3 による予測結果である. \#1, \#3, \#5 は接続管出 口の測定静圧を初期值として接続管入口の静圧を予測した場合である. 2 章では\#1, \#3, \#5 のように図 6 の出口 の状態を与えて入口の状態を予測する場合を説明したが，反対に入口の状態を与えて出口の状態を予測するもの にも容易に変更できる，\#2，\#4，\#6 は，接続管入口の測定静圧を初期值として接続管出口の静圧を予測した場合 である.

Method 1 では, 図 10(b)のように，\#1 の圧力差はすべてのレイノルズ数で実験值よりも約 $30 \%$ 大きい值となっ た. これに対し\#2 は，Re=371 では\#1 とほぼ同じ圧力差であるのに対し，Re の増加とともに\#1よりも低い圧 力差を予測するようになっている. 式(8)を用いて $\bar{\rho}^{2} / 2=\dot{m}^{2} /\left(2 \bar{\rho} A^{2}\right)$ と変形すると分かるように, 式(1)の圧力 損失は密度に反比例する，したがって\#2では，（主要な損失を生み出している流路要素で）\#1より高い密度を用 いて予測が行われたことになる. Method 1 では流路要素の密度を值が与えられている側の一定值として計算を行 っており, 図 6 で, \#1 は密度が小さい側の $\rho_{2}$ を, $\# 2$ では密度が大きい側の $\rho_{1}$ をつねに参照密度としている.（こ のことにより, Method 1 は\#1 より\#2 の方が低い圧力損失を計算する傾向を持っている.）予測の数值の詳細を見 たところ，9つの流路要素のうち出口から 2 番目にある H-I 間で最も大きな損失が計算されていた. 実験では表 3 のように低圧側の圧力を一定として高圧側の圧力を変化させているので，\#1 では H-I 間での参照密度である I の 密度が Re によらず低圧側一定值の密度に近い值となるのに対し, \#2 では高圧側の初期值密度が Re とともに増 加し, $\mathrm{H}$ の予測密度も増加した. このことにより H-I 間の圧力損失は\#2 の方が\#1 よりも小さく予測され, その差 は Re の増加とともに大きくなる.これが\#1 と\#2 の差が生じる理由である.

Method 1 では, 上述のように\#1 と\#2 で流路要素での参照密度の取り方が異なるので, 例えばある出口の初期 值に対して\#1 を実行し, 得られた入口の予測結果を初期值として\#2 を実行しても, 得られる予測結果はもとの初 期值と一致しない，これは方法自体に由来する誤差であり，陽的な方法で流路系圧縮性流れの予測を行う際に注 意を要する点である.

Method 2 では, \#3 の圧力差は実験值より 11\%〜16\%小さい值となり，\#1より実験值に近い。しかし\#4 は\#3 よ りもさらに小さい圧力差を予測し, レイノルズ数の増加とともに実験值との差が大きくなり, $R e=1460$ では実 験值に対して $-40 \%$ も差を有している. 入口（高圧側）を初期值とする\#4 の方が低い圧力差を予測しているが, その理由はMethod 1 とは本質的に異なる. まず, Method 2 では, ある出口の初期值を用いて井 で入口の圧力予 測を行い, その予測結果を初期值として\#4の予測を実行すれば, \#3で用いた出口の初期值を完全に逆算すること ができる.これを “逆算可能な”予測方法と呼ぶことにする. 逆算可能となるのは, 1 次元流れの連立方程式を 解くことで流路要素の $1 ， 2$ 間で一意に成り立つ状態を求めて予測を進めているからである. Method 2 も式(1)を 用いているから, 圧力損失は密度の逆数に比例する. 図 11(a)のように, 流路系の損失係数が過小に見積もられて いるとき, 逆算可能な予測方法で, 出口（低圧側）の測定静圧 $p_{\text {out }}$ を初期值として, 入口静圧を実験值より小さ く予測したとする．この予測值と実験值の差を D1 とする. 初期值をとる側を反対にし，入口（高圧側）の測定 静圧 $p_{\text {in }}$ を初期值として\#4 で出口の静圧を予測する. このとき, 先の予測結果（図 11(a)の三角のマーカー）がも し初期值であれば予測出口静圧は $p_{\text {out }}$ と一致するが, より大きな初期值 $p_{\text {in }}$ を用いるため, \#4 の予測結果は $p_{\text {out }}+\mathrm{D} 1$ よりも大きくなる，なぜなら全流路要素で\#4 の方が\#3 より密度が大きく, 損失が小さく計算されるからである. したがって, \#4 の予測結果と実験值の差を D2 とすれば, D1<D2 が成り立つ. 一方, 図 11(b)のように, 流路系 の損失係数が過大に見積もられているとき， $p_{\text {out }}$ を初期值として\#3で $p_{\text {in }}$ よりも大きな静圧を予測したとする. こ の予測結果を初期值として出口の静圧を\#4 で予測すると $p_{\text {out }}$ と一致するが, より小さい初期值 $p_{\text {in }}$ を用いた予測で 


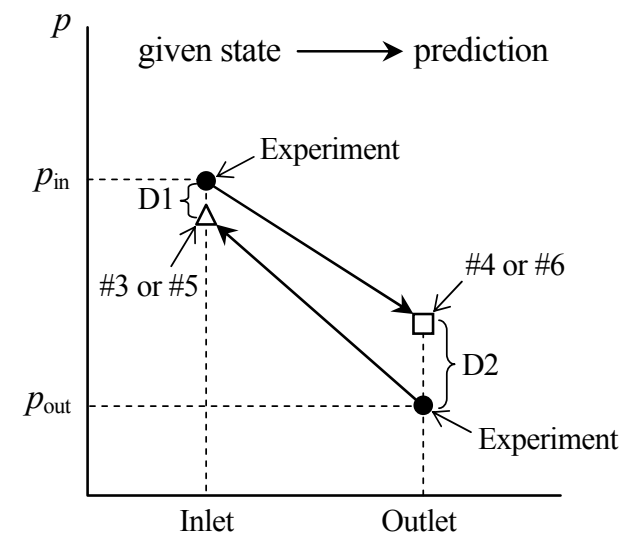

(a) Too small loss coefficient.

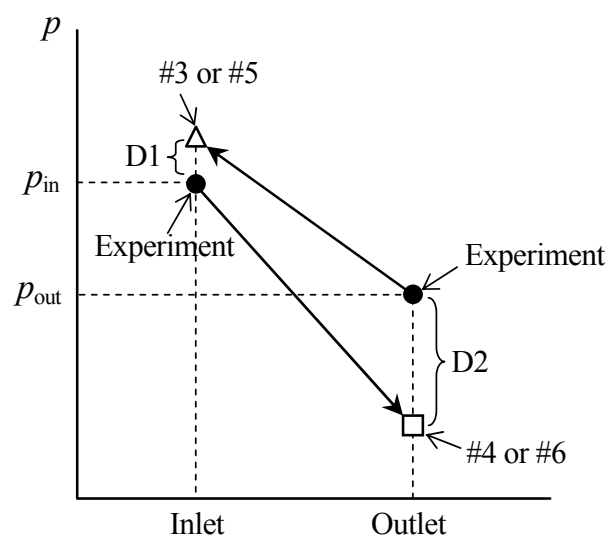

(b) Excessive loss coefficient.

Fig. 11 The method 2 and 3 (see caption of Fig. 10) are "backward calculable" prediction method. In backward calculable prediction, if \#3 predicts A by given outlet state B, \#4 predicts exact B by given inlet state A. (The same is said for \#5 and \#6.) For backward calculable prediction method, the difference of prediction from the experiment by given inlet state (higher pressure side) is always larger than that by given outlet state (lower pressure side). (D1 < D2 for both (a) and (b).)

は全流路要素で\#3 よりも密度が小さくなるから，\#3 よりも大きな圧力損失が計算され，やはり D1 < D2 が成り 立つ.したがって, 逆算可能な予測方法を用いる場合は低圧側を初期值とした方が実験值に近い值を予測できる， という結論を導くことができる. 実際, 2.5 節で定めた損失係数を仮想的に 1.5 倍にして損失を過大に見積もった ところ，\#3，\#4 はともに実験值の圧力差より大きい值を予測したが，全レイノルズ数範囲で\#3の方が実験值に近 かった. これは Method 1 の\#1 と\#2 の位置関係と反対であり，初期值をとる側を変えて生じる差の原因が本質的 に異なると述べたのはこのためである.

Method 2 の全圧損失計算を修正した Method 3 の予測結果\#5, \#6 では，図 10(b)のように，実験值との差は\#5 が $-3.9 \%$ 2.9\%, \#6 が-18\%〜 4.9\%となり, Method 2 と比べて実験值との一致が改善されている. Method 3 も逆算 可能な予測方法であり，式(16)より $\Delta h_{\mathrm{L}} \propto 1 / \rho^{2}$ となるので密度が小さい方が圧力損失を大きく予測する. した がって Method 2 に対し図 11 を用いて行ったのと同じ考察が成り立つ. 実際, 図 10(b)を見ると予測圧力差が実験 值より大きい場合，小さい場合のいずれも，\#5の予測結果の方が実験值に近い.

Method 3 でも，Re = 1220，1460では低圧側を初期值とした場合（\#5）の実験值と予測の差がそれぞれ-3.1\%, $-3.9 \%$ であたのが，高圧側を初期值とした場合（\#6）ではそれぞれ-12\%，-18\%となっており，Method 2 と同様 に差が拡大されているのが分かる. 実際の設計では上流側を初期值とした予測が必要なケースも想定されるため, このように差が拡大される問題を解決することは今後の課題である.

\section{$4 \cdot 2$ 圧力損失予測に及ぼす圧縮性の影響}

Method 2, 3 では図 4 の各地点 A〜J における $V, T$ が算出されるため, マッハ数 $M a=V / \sqrt{\kappa R T}$ の予測值 を計算できる. $R e=371,1460$ のときの各地点での $M a$ を図 12 に示す. $R e=371$ では, \#5 と\#3, \#4, \#6 の差 は最大で 0.011 と小さかったため, \#5 の結果のみを示している. 接続管 (A-B, I-J), マイクロチャンネル部 (E-F) では $M a$ は 0.04 0.07 の小な值をとるが，流路が狭小となるプレート出入口およびサポートブリッジ部（C， $\mathrm{D}, \mathrm{G}, \mathrm{H})$ では $M a$ が $0.2 \sim 0.3$ となっており, 圧縮性の影響が現れ始める $M a=0.3$ に近い值になっている. 図 10(a)(b)の圧力損失予測で, $R e=371$ のとき圧縮性を考慮した Method 3（\#5, \#6）の方が Method 2（\#3，\#4）よ りも実験值との一致が良くなるのはこのことが理由と考えられる. 次に図 12 の\#5では, Re = 1460 のとき流路 が狭小となる地点 $\mathrm{C}, \mathrm{D}, \mathrm{G}, \mathrm{H}$ の $M a$ は $0.4 \sim 0.7$ 程度まで上昇している. 一方，上流側接続管（A-B）およびマ イクロチャンネル部 $(\mathrm{E}-\mathrm{F})$ では, $R e$ の増加に伴う $M a$ の上昇は小さい. また, 上流側接続管と下流側接続管 (I-J) は寸法が同じであるが，密度が小さい下流側の方が $M a$ の上昇が大きい. 以上より，寸法が小さい地点，および 密度が小さくなる下流側の地点の方が， Re の増加に伴う $M a$ の上昇が大きいことが分かる. 


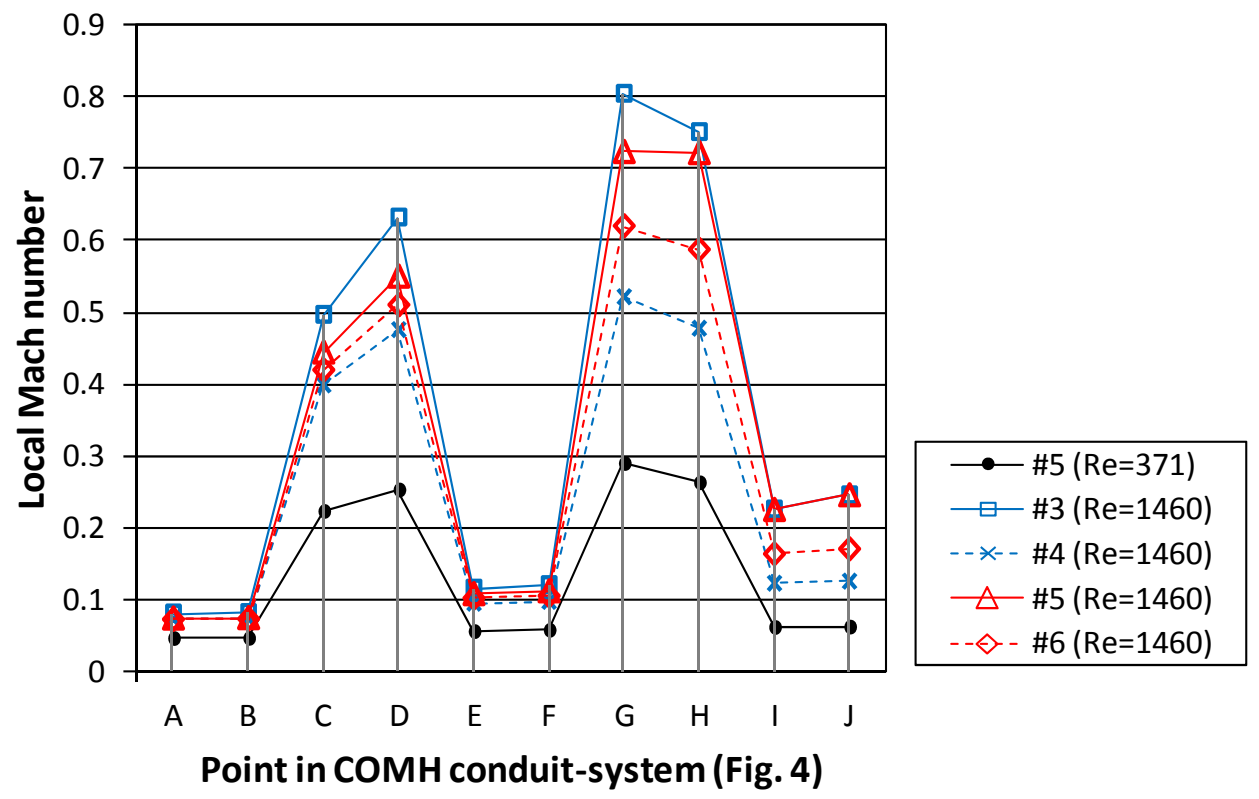

Fig. 12 Local Mach number predicted by the method 2 (\#3, \#4) and 3 (\#5, \#6). For Re $=371$, the results of \#3, \#4 and \#6 not shown in the figure almost coincide with \#5. Even when $R e=371$, Mach number takes a value of 0.2-0.3 at the narrow cross-sections C, D, G and H. Mach number increases with increasing Reynolds number, and becomes about 0.4-0.7 at the narrow cross-sections as can be seen from the result of $\# 5$ for $\mathrm{Re}=1460$. The difference depending on which pressure of inlet $\mathrm{A}(\# 4, \# 6)$ or outlet $\mathrm{J}(\# 3, \# 5)$ is used as the initial value of prediction is smaller for method 3 (\#5, \#6) than for method $2(\# 3, \# 4)$.

Table 4 Occupancy of pressure loss at each conduit-element to the whole predicted static pressure drop.

\begin{tabular}{c|c|c|c|c|c}
\hline \hline \multirow{2}{*}{$\begin{array}{c}\text { Channel } \\
\text { Reynolds } \\
\text { number }\end{array}$} & \multicolumn{4}{|c|}{ Predicted pressure loss by \#5 [kPa] (Occupancy rate to the whole predicted static pressure drop [\%]) } \\
\cline { 2 - 6 } & $\begin{array}{c}\text { Connection pipe } \\
\text { (A-B and I-J) }\end{array}$ & $\begin{array}{c}\text { Flow bending and } \\
\text { expansion/contraction } \\
\text { (B-C and H-I) }\end{array}$ & $\begin{array}{c}\text { Support bridge } \\
\text { (C-D and G-H) }\end{array}$ & $\begin{array}{c}\text { Conduit from bridge to } \\
\text { channel (D-E and F-G) }\end{array}$ & $\begin{array}{c}\text { Channel } \\
\text { (E-F) }\end{array}$ \\
\hline 371 & $1.41(4.18)$ & $14.5(42.8)$ & $3.31(9.81)$ & $10.8(32.1)$ & $3.76(11.1)$ \\
1460 & $11.4(4.92)$ & $149(64.2)$ & $35.1(15.1)$ & $28.2(12.1)$ & $8.46(3.64)$ \\
\hline \hline
\end{tabular}

なお, $R e=1460$ のときの\#3 と\#4, および\#5 と\#6 を比較すると, 特に流路が狭小となる地点 $\mathrm{C}, \mathrm{D}, \mathrm{G}, \mathrm{H}$ で, 上流側・下流側のどちらの実験值圧力を初期值として用いるかによって差が生じている. この差は Method 2 の井 3

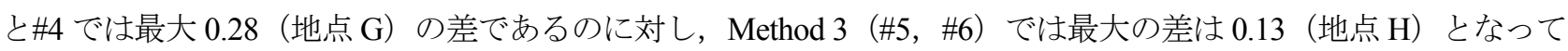
おり, Method 3 の方が小さい.

圧縮性流れでは損失係数がマッ八数 $M a$ に依存することがあると報告されている. 例えば, 層流の摩擦損失係 数は, $M a$ の増加に伴って非圧縮性流れの場合よりも大きくなる(村上，浅古，2011). 本論文の予測計算では, 損失係数の $M a$ 依存性は考慮しておらず，非圧縮性流れの損失係数をそのまま用いている。図 10(a)（または図 10(b)）の\#5 について, 圧力損失予測值の実験值からの差は， $R e=371$ では+0.95 kPa（+2.9\%）となり，モデル 化の過程で実際よりも損失を過大に評価したことになる。しかし，Re が大きくなると，予測值の圧力損失が実 験值より小さくなり， $R e=1460$ では実験值に対して-9.4 kPa (-3.9\%) となって, Re の増加に伴い予測值と実 験值の差が増加していることが分かる. 一方, 図 12 が示すように Re が増加すると各地点の $M a$ もきくなる. したがって, 図 4 の各流路要素に対する損失係数の $M a$ 依存性（あるいは非依存性）を明らかにして $M a$ を用い た具体的な式に整理できれば，予測を改善できると考えられる。 \#5 による圧力損失予測結果（図 10(a)）につい て, $R e=371,1460$ のときの各流路要素の損失の寄与を表 4 に示す. 最大きな損失が生じているのは，流路の $90^{\circ}$ 曲がり・急拡大 /急縮小でモデル化した B-C 間, H-I 間で，圧力損失全体の 50\%前後を占めている.また， 矩形流路の摩擦損失でモデル化した C-D-E 間, F-G-H 間を合わせると圧力損失全体の 30\%〜 40\%程度を占めてい 
る. これらの要素では $M a$ の上昇が大きいため, 曲がり・急拡大/急縮小を伴う流路, および任意のアスペクト 比の矩形流路の損失係数の $M a$ 依存性を明らかにし, 予測計算の損失係数に適用することが今後必要と考えられ る.

\section{5. 結 言}

本研究ではマイクロチャンネル熱交換器流路系を気体が流れる場合の圧力損失予測方法を検討寸るため, 流路 系を代表的な流路要素でモデル化し，非圧縮性流れの損失係数を用いて流路系全体の入口・出口の静圧差を予測 し，実験值と比較した３つの予測方法を検討して得られた結果は以下の通りである.

(1) 等温流を仮定し各流路要素で密度を一定とする予測方法は陽的に計算を進めることができ簡便であるが, 近似が多く含まれ，本研究の条件下では低圧側・高圧側のどちらを初期值とする場合も実験值との間に最 大で約 30\%の差が生じた.

（2）断熱流を仮定して 1 次元流れの連立方程式を解くことで予測を行う方法を提案した. この方法は陽的な予 測より近似が少なく，逆算可能な（ある初期值で予測を行い，その結果を初期值として逆方向に予測を行 うと，予測結果がもとの初期值と一致する）予測となり，理論的根拠が高められていると考えられる。こ の方法の中で非圧縮性流れの全圧損失の式を用いる場合は, 低圧側を初期值とする予測結果の実験值との 差は-11\%〜-16\%であった。

（3）逆算可能な予測方法で, 圧力損失を密度に反比例する形で評価する場合は, 損失係数が過小・過大のどち らであっても，低圧側を初期值とする方が実験值と近い予測が得られる.

（4）（2）の予測方法の中で, 非圧縮性流れの全圧損失の式を用いず，損失を散逸による発熱と捉えた後に全圧損 失に変換する方法を提案した。これを用いた予測では低圧側を初期值とする場合の実験值との差が-3.9\% 〜2.9\%に改善された.

\section{文献}

マイクロ・ナノ熱流体ハンドブック編集委員会編, マイクロ・ナノ熱流体ハンドブック(2006), p.126, エヌ・ティ 一・エス.

Hayase, G., Development of micro channel heat exchanger for residential air-conditioners, Proceedings of the 16th International Refrigeration and Air Conditioning Conference (2016), Paper 1566.

Hong, C., Nakamura, T., Asako, Y. and Ueno, I., Semi-local friction factor of turbulent gas flow through rectangular microchannels, International Journal of Heat and Mass Transfer, Vol.98 (2016), pp.643-649.

Kays, W. M. and London, A. L., Compact Heat Exchangers, 3rd ed. (1984), pp.36,113, Krieger Pub. Co.

Kohl, M. J., Abdel-Khalik, S. I., Jeter, S. M. and Sadowski, D. L., An experimental investigation of microchannel flow with internal pressure measurements, International Journal of Heat and Mass Transfer, Vol.48 (2005), pp.1518-1533.

Koyama, K. and Asako, Y., Experimental investigation on heat transfer characteristics of a gas-to-gas counterflow microchannle heat exchanger, Experimental Heat Transfer, Vol.23 (2010), pp.130-143.

村上信太郎, 浅古豊, 層流/乱流におけるマイクロチューブ圧縮性流れの局所管摩擦係数に関寸る研究, 日本機 械学会論文集 B 編, Vol.77, No.779 (2011), pp.1429-1444.

西道弘, 内部流れの損失, ターボ機械, Vol.21, No.6 (1993), pp.373-378.

Papautsky, I., Brazzle, J., Ameel, T. and Frazier, A., Laminar fluid behavior in microchannels using micropolar fluid theory, Sensors Actuators A, Vol.73 (1999), pp.101-108.

佐野正利, 佐川貴浩, 加藤玩真, 複数の分岐・合流部を有寸る矩形管内流れの圧力特性と流量分配, 日本機械学会 論文集, Vol. 83, No. 855 (2017), DOI:10.1299/transjsme.17-00395.

Sarvey, T. E., Zhang, Y., Zheng, L., Thadesar, P., Gutala, R., Cheung, C., Rahman, A. and Bakir, M. S., Embedded cooling technologies for densely integrated electronic systems, Proceedings of 2015 IEEE Custom Integrated Circuits Conference (CICC) (2015), pp.1-8.

妹尾泰利, 内部流れの力学 I. 運動量理論と要素損失・管路系 (1995), pp.13-14, 養賢堂.

Shah, R. K. and London, A. L., Laminar Flow Forced Convection in Ducts (1978), p.200, Academic Press.

管路・ダクトの流体抵抗出版分科会編, 管路・ダクトの流体抵抗 (1979), pp.54-55, 日本機械学会.

日本機械学会編，機械工学便覧 基礎編 $\alpha 5$ 熱工学 (2006), p.24. 
坪内為雄編, 熱交換器 (1968), p.60, 朝倉書店.

Tuckerman, D. B. and Pease, R. F. W., High-performance heat sinking for VLSI, IEEE Electron Device Letters, EDL-2 (1981), pp.126-129.

Yen, T., Kasagi, N. and Suzuki, Y., Forced convective boiling heat transfer in microtubes at low mass and heat fluxes, International Journal of Multiphase Flow, Vol.29 (2003), pp.1771-1792.

\section{References}

Editorial committee of handbook of micro- and nano- thermal fluids ed., Handbook of micro- and nano- thermal fluid (2006), p.126, NTS Co., Ltd. (in Japanese).

Hayase, G., Development of micro channel heat exchanger for residential air-conditioners, Proceedings of the 16th International Refrigeration and Air Conditioning Conference (2016), Paper 1566.

Hong, C., Nakamura, T., Asako, Y. and Ueno, I., Semi-local friction factor of turbulent gas flow through rectangular microchannels, International Journal of Heat and Mass Transfer, Vol.98 (2016), pp.643-649.

Kays, W. M. and London, A. L., Compact Heat Exchangers, 3rd ed. (1984), pp.36,113, Krieger Pub. Co.

Kohl, M. J., Abdel-Khalik, S. I., Jeter, S. M. and Sadowski, D. L., An experimental investigation of microchannel flow with internal pressure measurements, International Journal of Heat and Mass Transfer, Vol.48 (2005), pp.1518-1533.

Koyama, K. and Asako, Y., Experimental investigation on heat transfer characteristics of a gas-to-gas counterflow microchannle heat exchanger, Experimental Heat Transfer, Vol.23 (2010), pp.130-143.

Murakami, S. and Asako, Y., Local pipe friction factor of compressible laminar or turbulent flow in micro-tubes, Transactions of the Japan Society of Mechanical Engineers, Series B, Vol.77, No.779 (2011), pp.1429-1444 (in Japanese).

Nishi, M., Internal flow losses, Turbomachinery, Vol.21, No.6 (1993), pp.373-378 (in Japanese).

Papautsky, I., Brazzle, J., Ameel, T. and Frazier, A., Laminar fluid behavior in microchannels using micropolar fluid theory, Sensors Actuators A, Vol.73 (1999), pp.101-108.

Sano, M., Sagawa, T. and Kato, T., Pressure and flow rate characteristics of multiple-passage duct flows, Transactions of the JSME (in Japanese), Vol. 83, No. 855 (2017), DOI:10.1299/transjsme.17-00395.

Sarvey, T. E., Zhang, Y., Zheng, L., Thadesar, P., Gutala, R., Cheung, C., Rahman, A. and Bakir, M. S., Embedded cooling technologies for densely integrated electronic systems, Proceedings of 2015 IEEE Custom Integrated Circuits Conference (CICC) (2015), pp.1-8.

Senoo, Y., Dynamics of internal flow I. Momentum theory and loss of conduit-element/system (1995), pp.13-14, Yokendo Co., Ltd. (in Japanese).

Shah, R. K. and London, A. L., Laminar Flow Forced Convection in Ducts (1978), p.200, Academic Press.

Subcommittee of publishing fluid resistances in pipes and ducts ed., Fluid resistances in pipes and ducts (1979), pp.54-55, The Japan Society of Mechanical Engineers (in Japanese).

The Japan Society of Mechanical Engineers ed., JSME Mechanical Engineers' Handbook: Fundamentals $\alpha 5$ : Thermal Engineering (2006), p.24 (in Japanese).

Tsubouchi, T. ed., Heat exchanger (1968), p.60, Asakura Publishing Co., Ltd. (in Japanese).

Tuckerman, D. B. and Pease, R. F. W., High-performance heat sinking for VLSI, IEEE Electron Device Letters, EDL-2 (1981), pp.126-129.

Yen, T., Kasagi, N. and Suzuki, Y., Forced convective boiling heat transfer in microtubes at low mass and heat fluxes, International Journal of Multiphase Flow, Vol.29 (2003), pp.1771-1792. 